\title{
An anxiety-like phenotype in mice selectively bred for aggression
}

\author{
Derrick L Nehrenberga, ${ }^{a, b}$, , Ramona M Rodriguiz ${ }^{c}, \dagger$, Michel Cyr ${ }^{d}$, Xiaodong Zhang ${ }^{e}$, Jean M \\ Lauder $^{b}$, Jean-Louis Gariépy ${ }^{a}$, and William C. Wetsel ${ }^{f},{ }^{*}$ \\ aDepartment of Psychology, University of North Carolina at Chapel Hill, Chapel Hill, NC 27599, \\ USA
}

bDepartment of Cell and Developmental Biology, University of North Carolina at Chapel Hill, Chapel Hill, NC 27599, USA

'Department of Psychiatry and Behavioral Sciences, Mouse Behavioral and Neuroendocrine Analysis Core Facility, Duke University Medical Center, Durham, NC 27710, USA

dNeuroscience Research Group, University of Quebec at Trois-Rivieres, C.P. 500, Trois-Rivieres, Quebec G9A 5H7, Canada

eDepartment of Cell Biology, Duke University Medical Center, Durham, NC 27710, USA

fDepartments of Psychiatry and Behavioral Sciences, Cell Biology, and Neurobiology, Mouse Behavioral and Neuroendocrine Analysis Core Facility, Duke University Medical Center, Durham, NC 27710, USA

\section{Abstract}

Using selective bi-directional breeding procedures, two different lines of mice were developed. The NC900 line is highly reactive and attacks their social partners without provocation, whereas aggression in $\mathrm{NC100}$ animals is uncommon in social environments. The enhanced reactivity of NC900 mice suggests that emotionality may have been selected with aggression. As certain forms of anxiety promote exaggerated defensive responses, we tested NC900 mice for the presence of an anxiety-like phenotype. In the open field, light-dark exploration, and zero maze tests, NC900 mice displayed anxiety-like responses. These animals were less responsive to the anxiolytic actions of diazepam in the zero maze than NC100 animals; diazepam also reduced the reactivity and attack behaviors of NC900 mice. The NC900 mice had reduced diazepam-sensitive $\mathrm{GABA}_{\mathrm{A}}$ receptor binding in brain regions associated with aggression and anxiety. Importantly, there was a selective reduction in levels of the $\mathrm{GABA}_{\mathrm{A}}$ receptor $\mathrm{a}_{2}$ subunit protein in NC900 frontal cortex and amygdala; no changes in $a_{1}$ or $\gamma_{2}$ subunit proteins were observed. These findings suggest that reductions in the $a_{2}$ subunit protein in selected brain regions may underlie the anxiety and aggressive phenotype of NC900 mice. Since anxiety and aggression are comorbid in certain psychiatric conditions, such as borderline personality and posttraumatic stress disorder, investigations with NC900 mice may provide new insights into basic mechanisms that underlie these and related psychiatric conditions.

(C) 2009 Elsevier B.V. All rights reserved.

"Corresponding author: Tel.: +1-919-684-4574; fax: +1-919-684-3071. wetse001@mc.duke.edu..

${ }^{\dagger}$ Both authors contributed equally to this work.

Publisher's Disclaimer: This is a PDF file of an unedited manuscript that has been accepted for publication. As a service to our customers we are providing this early version of the manuscript. The manuscript will undergo copyediting, typesetting, and review of the resulting proof before it is published in its final citable form. Please note that during the production process errors may be discovered which could affect the content, and all legal disclaimers that apply to the journal pertain. 


\section{Keywords}

Selective breeding; Aggression; Anxiety; Diazepam; $\mathrm{GABA}_{\mathrm{A}}$ receptor binding; Benzodiazepine receptor subunits

\section{Introduction}

Currently, diagnoses of psychiatric disorders are made according to phenomenologic criteria [1] and the biologic bases of conditions are inferred from pharmacological actions of therapeutic drugs. As this approach is limited, some researchers have turned to using gainor loss-of-function mutants to develop animal models where certain symptoms of psychiatric conditions are recapitulated [14]. Alternatively, selective breeding strategies have been employed to develop lines of mice that have a high propensity to display certain endophenotypes [31]. Using the latter approach, the North Carolina (NC) lines of mice were developed [16,27]. NC900 mice are highly reactive and readily attack their social partners, whereas NC100 animals rarely attack and show non-agonistic approach behaviors and immobility in social situations. In rodents, attack behaviors are elicited in response to unavoidable contact with a proximal threatening stimulus, while immobility appears in response to distal threat to avoid detection [23]. Since attack behaviors potentially reflect a higher state of acute emotional response, NC900 attack behaviors may reflect higher baseline levels of emotionality, such as anxiety.

In humans, anxiety disorders are not commonly associated with aggression [1]. However, relationships between anxiety and aggression in borderline personality $[36,60]$ and posttraumatic stress disorder are well-known $[5,6,40]$. Interestingly, some patients diagnosed with anxiety disorders display atypical responses to benzodiazepines $[47,53,54]$ and exhibit attenuated benzodiazepine-sensitive $\mathrm{GABA}_{\mathrm{A}}$ receptor binding $[12,13,38,62]$. Due to these relationships, we have hypothesized that social reactivity and aggression in NC900 mice may reflect heightened anxiety and this may be associated with altered GABAergic function. Hence, the purpose of the present studies was to determine whether alterations in GABAergic function can be attributed to the increased aggression in the NC900 mice.

\section{Materials and methods}

\subsection{Animals}

NC100 and NC900 males (58-85 days of age) were obtained from the $44-46^{\text {th }}$ generations of selective breeding [16] at the University of North Carolina and Duke University. Briefly, NC100 and NC900 lines were derived from ICR mice. NC900 males that attacked most rapidly and frequently in the dyadic test were bred; NC100 males that failed to attack and showed freezing were used for breeding. Females within the same line whose male siblings had been selected were bred with non-related males. Once pregnant, females were individually housed until their pups were weaned at 21 days of age. Male $\mathrm{C} 3 \mathrm{H} / \mathrm{HeJ}$ mice (Jackson Laboratories, Bar Harbor ME) were used as test partners in the dyadic test [29,50]. As retinal degeneration can occur in this strain of mice, their visual acuity was assessed $24 \mathrm{~h}$ before social testing [50]. Animals were housed (cage size: $29.2 \times 18 \times 12 \mathrm{~cm}$ ) normally $3-4 /$ cage or at only $1 /$ cage for the dyadic test, and maintained under a 14:10 h light-dark cycle (lights on at $0700 \mathrm{~h}$ ) and were given rodent chow and water ad libitum. All experiments were conducted in accordance with the NIH Guide for the Care and Use of Laboratory Animals and with approved animal protocols from the University of North Carolina and the Duke University Medical Center. 


\subsection{Behavioral tests}

The NC100 and NC900 mice were age-matched when testing began. All mice were first tested in the zero maze, given a 7-10 day hiatus, then evaluated in the light-dark box or open field before being housed in isolation for at least 2 weeks prior to administering the social dyadic test. The mylorelaxant test was conducted in a separate set of mice that were approximately 10 weeks of age.

Activity was measured by photocells over $5 \mathrm{~min}$ in the open field $(21 \times 21 \times 30 \mathrm{~cm})$ and analyzed using the VersaMax program (AccuScan Instruments, Columbus, $\mathrm{OH}$ ) under $\sim 350$ lux [46]. Besides overall horizontal activity, activities in the center $(10 \times 10 \mathrm{~cm})$ and peripheral zones were examined. The light-dark exploration apparatus consisted of a mouse shuttle-box (MedAssociates, St. Albans, VT) with darkened ( 5 lux) and lighted chambers ( 600 lux) [26]. Mice were placed on the darkened-side, $5 \mathrm{sec}$ later the door to the adjoining chamber was opened, and mice were given free access to the entire apparatus for $5 \mathrm{~min}$. The latency to first enter the lighted side (i.e., 4 paws), time spent on each side, number of transitions between chambers, and activity (photocells) were determined by MedAssociates software. The zero maze test was administered as outlined [46]. Mice were placed into a closed area and given free access to the entire maze for $5 \mathrm{~min}$. Behavior was scored according to the percent of time in the open areas, latency to enter the open areas, and total numbers of transitions from one closed area to an open area to another closed area. The open field, light-dark exploration, and zero maze tests were conducted in an empty room between 1200-1800 h. Behaviors for the zero maze were videotaped in the absence of the investigator and analyzed using the Observer program (Noldus Information Technologies, Leesburg, VA).

Male NC mice were isolate-housed for 2 wks before the social dyadic test. Subsequently, $\mathrm{NC}$ animals were evaluated against an unfamiliar group-housed age- and weight-matched $\mathrm{C} 3 \mathrm{H}$ male in a novel environment. All testing was performed under red-light illumination (<5 lux), 1-4 h following onset of the dark cycle [50] in cages $(48.326 .8 \times 20.3 \mathrm{~cm}$; Allentown Caging, Allentown, NJ) that had been cleaned prior to or between each test with HI-CON 256 NPD detergent (CANI, Inc., Lansdale, PA) and dried. Clean irradiated 1/8" cob bedding (Andersen Inc., Maumee, $\mathrm{OH}$ ) was placed into the cage before testing. Mice were placed at opposite ends of the neutral cage and separated by a solid partition. After 5 min of acclimatization, the barrier was removed and animals were permitted to interact freely. Tests were terminated after $5 \mathrm{~min}$ of social interaction or if one of the mice initiated continuous attack for $30 \mathrm{sec}$. All tests were video-taped and coded by trained observers using the Observer program. Agreement between and within observers for all behaviors was assessed simultaneously using Cohen's $\kappa$ [3]; in all cases $\kappa>0.936$. Twenty-four behaviors were coded and organized into seven behavioral domains: immobility, mild social investigation (MSI), intensive social investigation (ISI), stationary reactivity (SR), locomotor reactivity (LR), threatening postures (TP), and attacks (see Supplementary Table S1) [50]. Since the occurrence of a single TP or attack will change the way in which social partners respond to one another [27,29,50], MSI, SR and LR were examined prior to the first agonistic exchange and these behaviors were expressed as percent time prior to the first agonistic exchange. TP and attacks were presented as the percent time relevant to the entire test.

\subsection{Diazepam treatment}

Diazepam (DZ; Sigma-Aldrich, St. Louis, MO) or vehicle (saline - 0.03\% Tween-80 solution) was given (i.p.) 30 min prior to behavioral testing. Parenthetically, DZ was used to pharmacologically confirm that the anxiety-like behaviors of NC900 mice would respond to an anxiolytic drug. The doses that were selected have been reported to be effective in the 
zero maze [46]; the doses chosen for the dyadic test do not produce myorelaxant effects in the wire-hang test for NC900 mice. We used the open field, light-dark box, and zero maze to demonstrate across tests that the NC900 mice display an anxiety-like phenotype. All three behavioral tests rely upon avoidance of an anxiogenic area (i.e., center zone, lighted area, open areas) as an index of anxiety-like behavior. We selected the zero maze because it is very sensitive to anxiolytic treatment [46]. In the zero maze NC100 and NC900 mice were administered vehicle, or $0.0625,0.125,0.250$, or $0.5 \mathrm{mg} / \mathrm{kg}$ DZ. In the rotorod and wirehang tests, mice were pre-trained for 2 days [55]. Each session lasted $2 \mathrm{~min}$ on the rotorod $(16 \mathrm{rpm})$ and $20 \mathrm{~s}$ on the horizontal wire, separated by $\sim 1 \mathrm{~min}$. On each day mice were given mock vehicle injections 30 min before testing. On day 3 mice were injected with vehicle or $1,2,5$, or $10 \mathrm{mg} / \mathrm{kg}$ DZ and evaluated $30 \mathrm{~min}$ later in both tests. Latencies to fall from the rotorod, grasp the horizontal wire with a rear paw, and fall from the wire were recorded. Mice that failed to fall from the rotorod within $60 \mathrm{~s}$ were assigned that latency. Likewise, mice that did not grasp the wire or fell within $10 \mathrm{~s}$ were assigned that score. In the contact righting test, mice were given vehicle, $0.1,1,3$, or $10 \mathrm{mg} / \mathrm{kg}$ DZ (i.p.) and tested $30 \mathrm{~min}$ later. The mouse was placed on its feet in a plastic tube $(5 \mathrm{~cm}$ in diameter $\mathrm{x} 22 \mathrm{~cm}$ long) and the tube was rapidly rotated $180^{\circ}$ for three consecutive trials [52]. The response was scored as: -6 for failure to right, -5 for $>5$ s delay in righting, -4 for $>2$ s delay in righting, -3 for $>1 \mathrm{~s}$ delay in righting, -2 for righting from back $<1 \mathrm{~s},-1$ for immediately rolling to the side and righting within $1 \mathrm{~s}$, and 0 for no delay in righting. In the dyadic test, only NC900 mice were administered $0.5,1.0$, or $1.5 \mathrm{mg} / \mathrm{kg} \mathrm{DZ}$; NC100 mice were not given DZ because they were not aggressive; $\mathrm{C} 3 \mathrm{H}$ test partners were not administered any drugs.

\subsection{Chromatography of $D Z$ and metabolites}

Six naïve adult, males/line were given vehicle or $3 \mathrm{mg} / \mathrm{kg}$ DZ (i.p.) and euthanized by cervical dislocation and decapitation $30 \mathrm{~min}$ after injection. Trunk blood was collected into $0.1 \mathrm{M}$ EDTA-treated tubes and centrifuged at $8,000 \mathrm{x}$ g for $10 \mathrm{~min}$ at $4^{\circ} \mathrm{C}$. Plasma was transferred to $0.1 \mathrm{M}$ EDTA-treated tubes and stored at $-80^{\circ} \mathrm{C}$. Samples from vehicle-treated mice were spiked with $100,250,500$, or $1000 \mathrm{ng} / \mathrm{ml} \mathrm{DZ,} N$-desmethyldiazepam (DDP), oxazapam (OXP), and temazepam (TMP; Sigma-Aldrich) to establish standard curves. Blank (vehicle-treated), spiked, and samples from DZ-treated mice were acidified with phosphoric acid, vortexed, cooled on ice for $10 \mathrm{~min}$, and centrifuged at 8,000 rpm for 20 min at $4^{\circ} \mathrm{C}$. Supernatants were loaded onto Waters Oasis MCX cartridges (Belmont, MA), washed sequentially with $0.1 \mathrm{~N} \mathrm{HCl}, 100 \%$ methanol $(\mathrm{MeOH})$, and $5 \% \mathrm{NH}_{4} \mathrm{OH}-25 \%$ $\mathrm{MeOH}$, and eluted with 5\% $\mathrm{NH}_{4} \mathrm{OH}-95 \% \mathrm{MeOH}$. Samples were lyophilized, reconstituted in mobile phase [20 mM phosphate buffer ( $\mathrm{pH} 7.0)$ in $66 \% \mathrm{MeOH}]$, sonicated, and filtered through $0.22 \mu \mathrm{m}$ Ultrafree-MC ${ }^{\mathrm{TM}}$ microfilters (Millipore Corporation, Bedford, MA) by centrifugation at $4,000 \mathrm{xg}$ for $2 \mathrm{~min}$ at room temperature (RT). Isocratic separations were achieved at $1.2 \mathrm{ml} / \mathrm{min}$ at RT on a $0.46 \times 250 \mathrm{~mm} 5 \mu \mathrm{m}$ 238DE C18 Vydac column (The Separations Group, Hisperia, CA), while absorbance was monitored at $232 \mathrm{~nm}$.

\subsection{Autoradiography of $D Z$ binding sites in brain}

Adult naïve NC100 and NC900 males were euthanized as described above and whole brains were frozen in dry-ice cooled with $N$-methylbutane. Twenty $\mu$ m coronal or sagittal sections were vacuum-dehydrated at $4^{\circ} \mathrm{C}$ for $1 \mathrm{~h}$. Slides were pre-incubated $2 \times 10$ min at $4{ }^{\circ} \mathrm{C}$ in 50 $\mathrm{mM}$ Tris- $\mathrm{HCl}-120 \mathrm{mM} \mathrm{NaCl}$ buffer (pH 7.4) with $10 \mathrm{nM}\left[{ }^{3} \mathrm{H}\right] \mathrm{Ro} 15-4513$ (Perkin Elmer, Boston, MA) for $60 \mathrm{~min}$ at $4^{\circ} \mathrm{C}$ to determine total $\mathrm{GABA}_{\mathrm{A}}$ receptor binding [see 33]. DZinsensitive receptors were determined when $100 \mu \mathrm{M} \mathrm{DZ}$ was included in the incubation buffer. Slides were washed $2 x$ for $30 \mathrm{sec}$ at $4^{\circ} \mathrm{C}$ in $50 \mathrm{mM}$ Tris- $\mathrm{HCl}(\mathrm{pH}$ 7.4), rinsed with water for $10 \mathrm{sec}$ at $4^{\circ} \mathrm{C}$, air-dried at RT, and exposed to Kodak Biomax MR film (Rochester, $\mathrm{NY}$ ) at $4^{\circ} \mathrm{C}$ for 7 wks. Tritium standards (American Radiolabeled Chemicals, St. Louis, MO) with known radioactivity levels were exposed simultaneously with brain sections and 
used for calibration curves. DZ-sensitive binding was determined by subtracting it from total $\mathrm{GABA}_{\mathrm{A}}$ receptor binding. Binding densities were quantified using Scion image software (version 1.63; Frederick, Maryland) and averaged from 3 brain sections/mouse. The mouse brain stereotaxic atlas of Paxinos and Franklin [45] was used as a guide to identify the brain regions of Ro15-4513 binding.

\subsection{Western blot of benzodiazepine receptor subunit proteins}

Brains from naïve NC100 and NC900 mice were removed as described above and $300 \mu \mathrm{m}$ coronal cryosections were taken from +3.20 to -2.30 bregma [45]. Micropunches $(0.5 \mathrm{~mm}$ and $1 \mathrm{~mm}$ diameter) from amygdala and frontal cortex were pooled separately from respective NC100 and NC900 mice to obtain sufficient protein. Punches were sonicated in ice-cold $10 \mathrm{mM}$ HEPES, $350 \mathrm{mM}$ sucrose, $5 \mathrm{mM}$ EDTA buffer (pH 7.4) containing Complete $^{\mathrm{TM}}$ Protease Inhibitor Cocktail (Roche, Indianapolis, IN). Homogenates were centrifuged at $2,000 \mathrm{xg}$ for $10 \mathrm{~min}$ at $4^{\circ} \mathrm{C}$. Supernatants were centrifuged at $100,000 \mathrm{xg}$ for $30 \mathrm{~min}$ at $4^{\circ} \mathrm{C}$ and the pellet was re-suspended in homogenization buffer; an aliquot was taken for protein assay [11]. Proteins were separated on NuPAGETM 4-12\% gels (Invitrogen, Carlsbad, CA) and transferred to $0.45 \mu \mathrm{M}$ Immobilon-P PVDF membranes (Millipore, Billerica, MA). Membranes were washed $2 \mathrm{x}$ for $10 \mathrm{~min}$ in $20 \mathrm{mM}$ Tris - $137 \mathrm{mM} \mathrm{NaCl}$ $0.1 \%$ Tween-20 (TBS-T) buffer (pH 7.6) and blocked in the same buffer using 5\% nonfat dry milk (TBS-T NFM) at RT for $1 \mathrm{~h}$. Blots were incubated in TBS-T NFM with $a_{1}, a_{2}$, or $\gamma_{2}$ subunit antisera (Alomone Labs, Jerusalem, Israel) at 1:750, 1:1000, and 1:1000 dilutions, respectively, for $1 \mathrm{~h}$ at RT. Following washing in TBS-T, blots were incubated in TBS-T NFM with horseradish peroxidase-linked anti-rabbit antiserum (1:10,000 dilution; Cell Signaling, Beverly, MA) for $1 \mathrm{~h}$ at RT. The blots were developed using ECL-Plus reagents (Amersham, Piscataway, NJ), visualized by a STORM 860 imager (Amersham), and quantified using the ImageQuant program (Amersham). Blots were stripped in $100 \mathrm{mM}$ 2-mercaptoethanol, $2 \% \mathrm{SDS}$, and $62.5 \mathrm{mM}$ Tris- $\mathrm{HCl}$ buffer $(\mathrm{pH} 6.7)$, incubated at $50^{\circ} \mathrm{C}$ for $30 \mathrm{~min}$, washed $2 \times 10 \mathrm{~min}$ in TBS-T, and processed using $\beta$-actin antiserum (1:500 dilution; AbCam, Cambridge, MA). The protein subunit density values were expressed relative to that for $\beta$-actin. As negative controls, $1 \mu \mathrm{g}$ of each subunit antiserum was pre-absorbed with 10 $\mu \mathrm{g}$ of each respective antigenic peptide (Alamone).

\subsection{RT-PCR analyses of expression of the $\alpha_{2}$ subunit of the benzodiazepine receptor}

Naïve mice were used in this experiment. Total RNA from NC100 and NC900 frontal cortex was prepared using TRI Reagent ${ }^{\circledR}$ RNA Isolation Reagent (Sigma). RNA was reverse transcribed and amplified by real-time PCR using Platinum ${ }^{\circledR}$ SYBR ${ }^{\circledR}$ Green qPCR SuperMix-UDG (Invitrogen). GABA receptor $a_{2}$ subunit cDNA was amplified with specific primers encompassing 5' (Forward: $5^{\prime}$-ACA TGC AAT GTA TGG TCT CTG CTG C; Reverse: 5'-TGT CTC CCA GTC CTG GTC TAA GC) and 3' regions (Forward: 5' TGA GGC TTA CAG TCC AAG CCG AAT G; Reverse: $5^{\prime}$-ATT TAA CCT GGA GCC ATC GGG AGC), respectively. The sample was denatured at $95^{\circ} \mathrm{C}$ for 3 min followed by 40 cycles of amplification at $95^{\circ} \mathrm{C}$ for $2 \mathrm{~s}, 60^{\circ} \mathrm{C}$ for $20 \mathrm{~s}$, and $72^{\circ} \mathrm{C}$ for $30 \mathrm{~s}$. Gene expression was normalized to GAPDH (Forward: $5^{\prime}$-ATG CCA TCA CTG CCA C(C/T)C AGA AG; Reverse: $5^{\prime}$-TGC CAG TGA GCT TCC CGT TCA G). The full-length $a_{2}$ subunit RT-PCR product was amplified and sequenced at the Duke Sequencing Facility.

\subsection{Statistics}

The data are presented as means and standard errors of the mean using the Statistical Package for the Social Sciences 11 (Chicago, IL). Line differences in the open field, lightdark exploration, zero maze, dyadic social tests, HPLC analysis, and DZ-sensitive $\mathrm{GABA}_{\mathrm{A}}$ receptor binding were evaluated by Student's $t$-tests. Univariate ANOVA was used to 
analyze drug responses in the zero maze, wire hang, rotorod, righting reflex, and dyadic social test. Post-hoc tests were by performed by Bonferroni corrected pair-wise comparisons. The percent animals completing the wire-hang test was determined by $\chi^{2}$ tests. A $p<0.05$ was considered significant.

\section{RESULTS}

\subsection{NC900 mice display anxiety-like behaviors}

In the open field, decreased activity in the center zone or increased thigmotaxis are considered as indices of anxiety in rodents [63,64]. Overall locomotor activities for NC100 $(312 \pm 40.5 \mathrm{~cm})$ and NC900 mice $(314 \pm 23.9 \mathrm{~cm})$ were indistinguishable. By comparison, NC900 animals spent less time in the center zone $[\mathrm{NC} 100=131 \pm 21.4$, NC900 $=68 \pm 17.6$ sec; $\left.t_{1,17}=2.302, p<0.035\right]$ and engaged in more thigmotaxis [NC100 $=159 \pm 18.2$, NC900 $\left.=233 \pm 17.6 \mathrm{~cm} ; t_{1,17}=2.316, p<0.039\right]$ than NC100 mice. In the light-dark exploration test, mice displaying anxiety-like behavior tend to avoid brightly lit environments [17]. NC900 mice spent less time on the lighted side $[\mathrm{NC100}=45 \pm 9.3$, NC900 $=17 \pm 7.1 \mathrm{sec}$; $t_{1,21}=2.342, p<0.029$ ], took longer to cross into this chamber [NC100 $=31 \pm 7.9$, NC900 $\left.253 \pm 27.6 \mathrm{sec} ; t_{1,21}=8.036, p<0.001\right]$, and crossed less frequently into the lighted side than NC100 animals [NC100 $=7.5 \pm 1.6, \mathrm{NC} 900=2.3 \pm 1.2$ times; $\left.t_{1,21}=2.397, p<0.026\right]$. In the zero maze, a reduction in percent of time in the open areas is an index of anxiety-like behavior [58]. NC900 mice spent less time in open areas [NC100 $=9.7 \pm 2.1 \%$, NC900 $=4.1$ $\pm 1.5 \% ; t_{1,16}=2.160, p<0.050$ ], took more time to enter the open areas [NC100 $=86 \pm 33.3$, $\left.\mathrm{NC} 900=209 \pm 34.4 \mathrm{sec} ; t_{1,16}=2.568, p<0.021\right]$, and engaged in fewer closed to open to closed area transitions than NC100 animals $[\mathrm{NC} 100=1.8 \pm 0.7, \mathrm{NC} 900=0.0 \pm 0.0$ transitions; $\left.t_{1,16}=2.399, p<0.029\right]$. Since NC900 mice spent less time in the center zone and showed enhanced thigmotaxis in the open field, avoided the lighted chamber in light-dark box, and spent less time in the open areas of the zero maze, the present results suggest the NC900 animals may display anxiety-like behaviors.

\subsection{NC900 mice are less responsive to $D Z$ than $N C 100$ animals}

Since NC900 mice appear to exhibit anxiety-like behaviors, animals were administered DZ to determine whether this anxiolytic drug would alleviate these behaviors in the zero maze. The ANOVA for percent time in the open areas failed to reveal significant main effects of mouse line $\left[F_{1,77}=0.247, p=0.621\right]$; however, effects of treatment $\left[F_{4,77}=3.046, p<0.022\right]$ and the mouse line by treatment interaction $\left[F_{4,77}=22.395, p<0.001\right]$ were significant (Fig. 1A). Bonferroni corrected pair-wise comparisons showed that vehicle-treated NC900 mice spent less time in the open areas than NC100 animals $(p<0.048)$. The $0.0625 \mathrm{mg} / \mathrm{kg}$ dose of $\mathrm{DZ}$ dramatically increased open area time for $\mathrm{NC100}$ mice relative to their vehicle controls $(p<0.001)$, whereas this dose was ineffective in NC900 animals. Although $0.125,0.25$, and $0.5 \mathrm{mg} / \mathrm{kg}$ DZ did not alter open area time in NC100 animals relative to vehicle, the two highest doses increased open area times in NC900 animals compared to their vehicle control $(p s<0.008)$ and to similarly-treated NC100 mice $(p s<0.001)$. Hence, DZ increased open area time in both mouse lines, but higher doses of $\mathrm{DZ}$ were required to alleviate the anxiety-like responses in NC900 animals.

An examination of latency to enter the open area of the zero maze revealed a similar effect (Fig. 1B). ANOVA failed to find significant effects of mouse line $\left[F_{1,77}=0.516, p=0.475\right]$, but significant treatment effects $\left[F_{4,77}=4.756, p<0.002\right]$ and a significant mouse line by treatment interaction emerged $\left[F_{4,77}=13.772, p<0.001\right]$. Bonferroni comparisons demonstrated that vehicle-treated NC900 mice entered the open areas more slowly than $\mathrm{NC} 100$ animals $(p<0.001)$. Although the latency to enter the open areas by $\mathrm{NC} 100$ mice was the lowest with $0.125 \mathrm{mg} / \mathrm{kg}$ DZ, it was not significantly different from vehicle. By contrast, 
the latency for NC100 animals to enter the open areas was increased with $0.25 \mathrm{mg} / \mathrm{kg} \mathrm{DZ}$ $(p<0.025)$. In NC900 mice, $0.125,0.25$, and $0.5 \mathrm{mg} / \mathrm{kg}$ DZ reduced the latency to enter the open areas relative to their vehicle control ( $p s<0.002$ ). At 0.25 and $0.5 \mathrm{mg} / \mathrm{kg} \mathrm{DZ,} \mathrm{NC900}$ mice entered the open areas more quickly than $\mathrm{NC} 100$ animals given the same doses $(p s<0.050)$.

The numbers of transitions from closed to open to closed areas in the zero maze were evaluated (Fig. 1C). ANOVA only revealed a significant mouse line by treatment interaction $\left[F_{4,77}=7.029, p<0.001\right]$. Bonferroni tests observed vehicle-treated NC900 mice made fewer transitions than NC100 animals $(p<0.005)$. Although transitions with NC100 mice were decreased with 0.25 and $0.5 \mathrm{mg} / \mathrm{kg} \mathrm{DZ}$, these values were not significantly different from their vehicle control. This suggests transitions are at a maximum for $\mathrm{NC100} \mathrm{mice} \mathrm{as} \mathrm{motor}$ performance may be affected at higher doses (see motor performance results below). By comparison, $0.5 \mathrm{mg} / \mathrm{kg}$ DZ enhanced transitions in NC900 animals relative to the vehicle $(p<0.001)$. This dose of DZ was sufficient to increase transitions of NC900 mice to levels of the NC100 vehicle-treated animals.

To determine whether the NC900 line had a more widespread deficiency in DZ responses, animals were evaluated for myorelaxant and motor-impairing effects of the drug. For latency to grasp the horizontal wire (Fig. 2A), ANOVA demonstrated main effects of mouse line $\left[F_{1,100}=31.427, p<0.001\right]$ and treatment $\left[F_{4,100}=66.220, p<0.001\right]$, and a significant mouse line by treatment interaction $\left[F_{4,100}=6.442, p<0.001\right]$. Bonferroni comparisons found vehicle-treated NC100 and NC900 mice had similar latencies to grasp the horizontal wire. For all doses of DZ, NC100 animals took longer to reach and grasp the wire than their vehicle controls $(p s<0.001)$. Although the latency to grasp was shorter with 1 than with 10 $\mathrm{mg} / \mathrm{kg}$ DZ for NC100 mice $(p<0.017)$, no differences were discerned among the other doses. NC900 mice given 2,5 , or $10 \mathrm{mg} / \mathrm{kg}$ DZ took longer to grasp the wire relative to their vehicle controls $(p s<0.001)$.

The duration of wire hang was also examined (Fig. 2B). ANOVA showed significant effects of mouse-line $\left[F_{1,100}=20.713, p<0.001\right]$, treatment $\left[F_{4,100}=24.637, p<0.001\right]$, and a significant line by treatment interaction $\left[F_{4,100}=3.134, p<0.018\right]$. Bonferroni tests noted that durations of wire hanging for vehicle-treated NC100 and NC900 mice were similar. For NC100 animals, all doses of DZ reduced wire hanging relative to their vehicle controls $(p s<0.012)$ and mice given 5 and $10 \mathrm{mg} / \mathrm{kg} \mathrm{DZ}$ remained on the horizontal wire for less time than animals administered 1 or $2 \mathrm{mg} / \mathrm{kg} \mathrm{DZ} \mathrm{(} p s<0.025$ ). By contrast, only NC900 animals given $10 \mathrm{mg} / \mathrm{kg} \mathrm{DZ} \mathrm{had} \mathrm{shorter} \mathrm{wire-hang} \mathrm{times} \mathrm{than} \mathrm{their} \mathrm{vehicle} \mathrm{controls}(p<0.002)$. Interestingly, wire-hang durations were longer for NC900 animals compared to NC100 animals at all doses of DZ examined $(p s<0.043)$. Hence, NC900 animals were less responsive to the myorelaxant effects of DZ than NC100 mice.

To examine motor-impairing effects of DZ, animals were tested on the rotorod (Fig. 2C). ANOVA revealed significant effects of mouse line $\left[F_{1,100}=4.809, p<0.031\right]$ and treatment $\left[F_{4,100}=75.481, p<0.001\right]$; no significant mouse line by treatment interaction was noted. Responses of vehicle-treated NC100 or NC900 mice were similar. Bonferroni tests reported that both $\mathrm{NC} 100$ and NC900 animals showed significant dose-dependent reductions in latencies to fall relative to their vehicle controls ( $p s<0.039$ ), with the shortest latencies occurring with the highest doses. Thus, rotorod performance was not distinguished by mouse line.

In the contact righting reflex test (Fig. 2D), an ANOVA found mouse-line $\left[F_{1,92}=35.280\right.$, $p<0.001]$, treatment $\left[F_{4,92}=28.661, p<0.001\right]$, and the mouse-line by treatment interaction to be significant $\left[F_{4,92}=4.915, p<0.001\right]$. NC100 mice responded to all 4 doses of DZ 
( $p s<0.034)$, whereas NC900 animals only responded to the two highest doses $(p s<0.017)$.

NC900 mice were less responsive to the motor impairing effects of DZ than NC100 animals $(p<0.001)$ and these effects were evident at all doses of DZ $(p s<0.038)$. Collectively, these findings show that while both mouse lines respond to DZ, the NC900 mice are generally less responsive to the anxiolytic, myorelaxant, and motor-impairing effects of the drug than NC100 animals.

\subsection{Metabolism of DZ is similar in NC100 and NC900 mice}

One reason why the NC900 animals show reduced responses to DZ may be because they may metabolize the drug more rapidly than $\mathrm{NC100} \mathrm{mice.} \mathrm{DZ} \mathrm{and} \mathrm{its} \mathrm{metabolites} \mathrm{were}$ examined 30 min after injection, the same time that all behaviors were assessed after DZ administration. As expected, no DZ or metabolites were detected in the vehicle controls. Levels of DDP $(395 \pm 117.2$ and $619 \pm 255.8 \mathrm{ng} / \mathrm{ml})$ and $\mathrm{OXP}(413 \pm 74.8$ and $313 \pm 51.0 \mathrm{ng} /$ $\mathrm{ml}$ ) were not significantly different between the respective NC100 and NC900 lines; levels of TMP were undetectable. These data indicate that the differential behavioral responses of NC100 and NC900 mice to DZ may not be attributed to alterations in DZ metabolism.

\subsection{DZ-sensitive binding is reduced in NC900 mice}

An alternative explanation for the reduced sensitivity of NC900 animals to DZ may be due to a reduction in the numbers of DZ-sensitive $\mathrm{GABA}_{\mathrm{A}}$ receptors. As there was no detectable DZ-insensitive binding outside the cerebellum (data not shown), total $\left[{ }^{3} \mathrm{H}\right] \mathrm{Ro} 15-4513$ binding was considered to reflect DZ-sensitive binding (Fig. 3). Binding in the frontal cortex $\left[t_{1,10}=2.690, p<0.023\right]$, mitral layer of the olfactory bulb $\left[t_{1,10}=6.155, p<0.001\right]$, lateral amygdala $\left[t_{1,10}=2.795, p \mathrm{~s}<0.019\right]$, ventromedial hypothalamus $\left[t_{1,10}=2.947, p<0.015\right]$, CA $1\left[t_{1,10}=4.110, p s<0.002\right]$ and CA3 hippocampus $\left[t_{1,10}=2.449, p<0.034\right]$, dentate gyrus $\left[t_{1,10}=5.660, p s<0.001\right]$, basolateral amygdala $\left[t_{1,10}=3.872, p<0.003\right]$, periaqueductal gray $\left[t_{1,10}=5.293, p<0.001\right]$, and posterior cortical amygdala $\left[t_{1,9}=3.543, p<0.006\right]$ were significantly reduced in the NC900 compared to the NC100 males.

\section{6. $\mathrm{GABA}_{\mathrm{A}}$ receptor $\alpha_{2}$ subunit protein levels are reduced in NC900 mice}

The decrease in DZ-sensitive binding in NC900 mice may be due to a reduction in protein levels of one or more subunits that comprise the benzodiazepine receptor. Since there is considerable evidence that benzodiazepine receptor binding occurs at the interface of the a and $\gamma_{2}$ subunits [8] and because the $a_{1}$ and $a_{2}$ subunits are critical for specific DZ responses [37,55], levels of $a_{1}, a_{2}$, and $\gamma_{2} \mathrm{GABA}_{\mathrm{A}}$ receptor subunit proteins were examined. As NC900 mice display anxiety-like behaviors and because they have decreased DZ binding in brain areas associated with anxiety, levels of subunit proteins were quantified by Western blot in the frontal cortex and amygdala. The $\alpha_{1}, \alpha_{2}$, and $\gamma_{2}$ subunits and $\beta$-actin immunopositive bands were detected at approximately $49,59,49$, and $43 \mathrm{kDa}$, respectively (Fig. 4A). Although no appreciable line differences were observed in levels of $a_{1}$ (Fig. 4B, middle) or $\gamma_{2}$ subunit proteins (Fig. 4B, bottom) or $\beta$-actin, concentrations of the $a_{2}$ subunit protein in NC900 mice were reduced by $31 \pm 4 \%$ in frontal cortex and by $40 \pm 7 \%$ in amygdala compared to levels in the same brain regions from NC100 animals (Fig. 4B, top). Selective reductions in the $a_{2}$ subunit protein, but not the $a_{1}$ or $\gamma_{2}$ subunit proteins, are consistent with decreased DZ-binding in NC900 animals, as well as, their reduced behavioral responses to the drug.

Since the $a_{2}$ subunit protein was reduced in NC900 mice, quantitative RT-PCR with oligonucleotides encompassing the $\mathrm{N}$-terminal and $\mathrm{C}$-terminal coding regions of the $\mathrm{a}_{2}$ subunit mRNA were used to determine whether mRNA levels were also decreased in these mice. After normalizing to GAPDH mRNA, no significant differences were detected between NC100 and NC900 mice in expression of portions of the $a_{2}$ subunit mRNA that 
encode the $\mathrm{N}$-terminal ( $100 \pm 0.17$ versus $98.33 \pm 0.50$ units) or C-terminal ( $100 \pm 1.00$ versus $99.17 \pm 1.25$ units) regions of the protein. Sequencing the full-length mRNA transcripts also failed to detect any polymorphisms between mouse lines (data not shown). Differential results for quantification of the $\alpha_{2}$ subunit mRNA and protein suggest that post-translational events that control $a_{2}$ subunit protein levels are different between NC100 and NC900 mice.

\subsection{Aggression in NC900 mice is reduced by DZ}

As anticipated, $\mathrm{NC} 100$ mice showed immobility in the dyadic social test when investigated by its $\mathrm{C} 3 \mathrm{H}$ partner and the latency to engage in this behavior was relatively rapid, occurring within the first min of testing (Table 1). By contrast, NC900 mice rarely displayed this response during dyadic testing. When paired with $\mathrm{C} 3 \mathrm{H}$ partner animals, analyses of behaviors by NC100 and NC900 mice revealed the anticipated line differences in social interaction (Fig. 5) that have been previously reported in the literature [16,27-29]. In the present studies, we report for the first time, the behaviors of the $\mathrm{C} 3 \mathrm{H}$ partner animals towards the NC100 or NC900 target mice during the dyadic test. Although C3H social partners rarely initiated attacks towards target mice, analyses of their behavioral responses juxtaposed to those of the NC100 or NC900 targets provides a more complete analysis of social behaviors in the dyadic test and they help to show whether the NC900 mice are initiating offensive or defensive responses.

For vehicle-treated mice, two-way ANOVA were conducted to examine the effects of mouse-line (i.e., NC100 and NC900) and mouse-type (i.e., target and partner) for each behavioral domain. The latencies to engage in MSI and ISI were prolonged, whereas those for SR, LR, TP, and attacks were decreased in NC900 males (Table 2). No line differences were observed between the target animals and the $\mathrm{C} 3 \mathrm{H}$ test partners for MSI (Fig. 5A, left panel). By contrast, NC900 animals spent less time in ISI compared to NC100 males and this line difference was reflected in the responses of the $\mathrm{C} 3 \mathrm{H}$ partners (Fig. 5B, left panel). ANOVA found significant main effects of mouse-line $\left[F_{1,36}=54.117, p<0.001\right]$; however, mouse-type or the interaction between these two main effects was not significant. Bonferroni corrected pair-wise comparisons confirmed that $\mathrm{NC} 900$ mice and their $\mathrm{C} 3 \mathrm{H}$ test partners rarely initiated ISI towards each other compared to NC100 males and their partners ( $p s<0.001)$. NC900 animals and their $\mathrm{C} 3 \mathrm{H}$ partners spent more time in SR than NC100 targets and their partners (Fig. 5C, left panel). ANOVA revealed significant main effects of mouse-line $\left[F_{1,36}=22.298, p<0.001\right]$; mouse-type and the interaction were not significant. Bonferroni comparisons showed that NC900 males and their test partners engaged in more SR towards each other than NC100 mice and their partners ( $p s<0.001)$. Interestingly, only NC900 males displayed LR (Fig. 5D, left panel). ANOVA noted significant effects of mouse-line $\left[F_{1,36}=32.918, p<0.001\right]$ and mouse-type $\left[F_{1,36}=64.585, p<0.001\right]$, and the line by mouse-type interaction was significant $\left[F_{1,36}=16.899, p<0.001\right]$. Bonferroni tests observed that NC900 males had higher rates of LR compared to NC100 males and all C3H test partners $(p s<0.002)$. NC900 mice also initiated more TP (Fig. 5E, left panel) and attacks (Fig. 5F, left panel) than NC100 animals and all $\mathrm{C} 3 \mathrm{H}$ partners. ANOVA for TP identified significant effects for mouse-line $\left[F_{1,36}=5.874, p<0.018\right]$, mouse-type $\left[F_{1,36}=9.419\right.$, $p<0.003]$ and the interaction between the two main effects $\left[F_{1,79}=5.385, p<0.023\right]$. Bonferroni corrected pair-wise comparisons demonstrated that NC900 animals executed more TP than NC100 mice or all $\mathrm{C} 3 \mathrm{H}$ partners $(p s<0.002)$. ANOVA for attacks also revealed significance main effects of mouse-line $\left[F_{1,36}=27.458, p<0.001\right]$ and mouse-type $\left[F_{1,36}=63.097, p<0.001\right]$, and the interaction was significant $\left[F_{1,36}=27.458, p<0.001\right]$. Bonferroni tests observed that NC900 males spent more time in attack behaviors than all other mice $(p s<0.001)$. In summary, the vehicle-treated NC900 mice were less likely to engage in ISI, and were more likely to spend time in SR, LR, TP and attacks than vehicletreated $\mathrm{NC} 100$ mice and their $\mathrm{C} 3 \mathrm{H}$ partners. Additionally, $\mathrm{NC} 900$ mice and their $\mathrm{C} 3 \mathrm{H}$ 
partners spent less time in ISI and more time in SR compared to NC100 animals and their partners. Notably, the $\mathrm{C} 3 \mathrm{H}$ partners rarely engaged in LR, TP or attacks. Together, these data demonstrate that NC900 males show heightened reactivity and aggression in a dyadic social test, even when paired with a non-threatening $\mathrm{C} 3 \mathrm{H}$ social partner.

Since only NC900 mice displayed an anxiety-like phenotype, had reductions of benzodiazepine receptors in various brain areas related to anxiety, and were aggressive, only these males were tested with DZ to determine whether their aggressive responses could be attenuated or eliminated with this anxiolytic drug. The latencies to engage in immobility for NC900 mice, we not affected by DZ treatments (Table 1). By comparison the latencies for MSI were reduced, while those for ISI, SR, LR, TP and attacks were protracted by DZ for NC900 males (Table 2). For the percent time spent in MSI for DZ-treated NC900 mice (Fig. $5 \mathrm{~A}$, right panel), ANOVA found significant main effects of mouse-type $\left[F_{1,76}=10.122\right.$, $p<0.001]$ and treatment $\left[F_{3,76}=14.911, p<0.001\right]$; the mouse-type by treatment interaction was also significant $\left[F_{3,76}=7.275, p<0.002\right]$. Bonferroni corrected pair-wise comparisons revealed that MSI was enhanced by $0.5 \mathrm{mg} / \mathrm{kg}$ DZ relative to the vehicle-control in NC900 males ( $p<0.001)$; no significant effects were observed with 1 or $1.5 \mathrm{mg} / \mathrm{kg}$ DZ. Contrasts within dose showed that NC900 males given 0.5 or $1 \mathrm{mg} / \mathrm{kg}$ DZ engaged in more MSI than their $\mathrm{C} 3 \mathrm{H}$ partners $(p s<0.017)$. Compared to $\mathrm{C} 3 \mathrm{H}$ mice paired with vehicle-treated NC900 males, MSI in the partners was reduced when NC900 males were given 1 or $1.5 \mathrm{mg} / \mathrm{kg} \mathrm{DZ}$ $(p s<0.036)$. For ISI (Fig. 5B, right panel), ANOVA demonstrated significant main effects of mouse-type $\left[F_{1,76}=6.130, p<0.014\right]$ and treatment $\left[F_{3,76}=10.122, p<0.001\right]$; the interaction was also significant $\left[F_{3,76}=4.202, p<0.004\right]$. Bonferroni tests observed that compared to vehicle, only 1 and $1.5 \mathrm{mg} / \mathrm{kg}$ DZ increased ISI for NC900 males $(p s<0.001)$. Although ISI was similar between the target and partner mice when NC900 males were treated with vehicle or $0.5 \mathrm{mg} / \mathrm{kg}$ DZ, NC900 males given 1 or $1.5 \mathrm{mg} / \mathrm{kg}$ DZ displayed more ISI than their $\mathrm{C} 3 \mathrm{H}$ partners $(p s<0.047)$. Compared to the $\mathrm{C} 3 \mathrm{H}$ mice paired with the NC900 vehiclecontrol, the $\mathrm{C} 3 \mathrm{H}$ males saw an increase in ISI $(p<0.006)$ when the NC900 males were administered $1 \mathrm{mg} / \mathrm{kg}$ DZ. For SR (Fig. 5C, right panel), ANOVA reported mouse-type $\left[F_{1,76}=60.023, p<0.001\right]$, treatment $\left[F_{3,76}=3.954, p<0.010\right]$, and the interaction to be significant $\left[F_{3,76}=2.959, p<0.048\right]$. Bonferroni post-hoc comparisons revealed that all three doses of DZ reduced SR for NC900 males relative to the vehicle control ( $p s<0.047)$. Within treatment, 1 and $1.5 \mathrm{mg} / \mathrm{kg}$ DZ reduced SR to greater extents than the $0.5 \mathrm{mg} / \mathrm{kg}$ dose $(p s<0.036)$. With respect to $\mathrm{C} 3 \mathrm{H}$ partners, SR was decreased when NC900 mice were given $1.5 \mathrm{mg} / \mathrm{kg}$ DZ compared to partners paired with the vehicle control or with targets given 0.5 or $1 \mathrm{mg} / \mathrm{kg}$ DZ ( $p s<0.045$ ). Nevertheless, under all DZ treatments NC900 mice continued to show less SR than their C3H partners $(p s<0.013)$. For LR (Fig. 5D, right panel), ANOVA observed the effects of mouse-type $\left[F_{1,76}=21.761, p<0.001\right]$ and treatment $\left[F_{3,76}=18.683\right.$, $p<0.001]$, and the interaction to be significant $\left[F_{3,76}=19.602, p<0.001\right]$. Bonferroni comparisons noted that all doses of DZ suppressed LR for NC900 males relative to vehicle $(p s<0.001)$. In this way, DZ eliminated differences in LR between NC900 males and their partners. For TP (Fig. 5E, right panel), ANOVA revealed significant main effects of mousetype $\left[F_{1,90}=5.874, p<0.018\right]$ and treatment $\left[F_{1,76}=9.419, p<0.003\right]$, and the interaction between these two main effects was significant $\left[F_{3,76}=5.383, p<0.023\right]$. Bonferroni tests showed relative to NC900 vehicle-controls, 1 and $1.5 \mathrm{mg} / \mathrm{kg}$ DZ increased TP $(p s<0.048)$ while $0.5 \mathrm{mg} / \mathrm{kg}$ DZ exerted little effect on these behaviors. Irrespective of the DZ dose given NC900 mice, C3H partners showed less TP than NC900 targets $(p s<0.012)$.

Nevertheless, TP was significantly enhanced in partners paired with NC900 males given 1.5 $\mathrm{mg} / \mathrm{kg}$ DZ. Additionally, TP by C3H males paired with vehicle-treated NC900 mice was increased when partners were paired when NC900 mice were given $0.5,1$, or $1.5 \mathrm{mg} / \mathrm{kg} \mathrm{DZ}$ $(p s<0.037)$. With regards to attack behaviors (Fig. 5F, left panel), ANOVA demonstrated significant main effects of mouse-type $\left[F_{1,76}=50.300, p<0.001\right]$ and the interaction between treatment and mouse-type was significant $\left[F_{3,76}=5.485, p<0.001\right]$. Bonferroni tests showed 
that 1 and $1.5 \mathrm{mg} / \mathrm{kg}$ DZ decreased attacks for NC900 males relative to vehicle ( $p \mathrm{~s}<0.001$ ) and the $0.5 \mathrm{mg} / \mathrm{kg}$ dose $(p s<0.014)$. The frequencies of attacks were augmented in $\mathrm{C} 3 \mathrm{H}$ partners paired with NC900 mice given 1 or $1.5 \mathrm{mg} / \mathrm{kg}$ DZ compared to C3H males paired with vehicle-treated NC900 animals $(p s<0.040)$. Although C3H males showed significantly fewer attacks towards the NC900 mice given vehicle or $0.5 \mathrm{mg} / \mathrm{kg}$ DZ ( $p \mathrm{~s}<0.001$ ), these differences vanished when NC900 targets were given 1 or $1.5 \mathrm{mg} / \mathrm{kg}$ DZ. It should be emphasized that despite the ability of DZ to reduce attacks in NC900 males and to increase attacks and $\mathrm{TP}$ in the $\mathrm{C} 3 \mathrm{H}$ mice, the partner animals were never the first to initiate agonistic responses in any of the tests. Intriguingly, because SR by $\mathrm{C} 3 \mathrm{H}$ partners was reduced while TP and attacks were enhanced, these findings suggest that the nature of the social interaction between the NC900 and $\mathrm{C} 3 \mathrm{H}$ animals was changed as a function of the NC900 males being treated with DZ. Together, these findings show that DZ can enhance social interactions in the NC900 males by increasing ISI and reducing reactivity; thereby, shifting aggressive behavior to less intense threatening responses.

A more detailed analysis of the individual behaviors that compose MSI, ISI, SR, TP, and attacks can be found in Supplementary Figures S1 and S2 and the companion ANOVA results are reported in Supplementary Tables S2 and S3. LR is not presented as this domain is unidimensional and is composed only of escapes or rapid departures; jump responses were not observed in the NC100, NC900, and C3H mice. For MSI, the NC100 mice were more likely to approach the unfamiliar $\mathrm{C} 3 \mathrm{H}$ partner and initiate the social interaction than NC900 males (Supplementary Figs. S1A-S1B). By comparison, C3H partners paired with NC900 mice always initiated the interaction. Once the interaction began, NC900 animals engaged in more sniffing than $\mathrm{NC100}$ mice; $\mathrm{C} 3 \mathrm{H}$ partners show similar levels of sniffing to both $\mathrm{NC}$ mouse lines. Examination of ISI (Supplementary Figs. S1D-S1E) found that NC100 mice and their partners spent similar amounts of time engaged in nosing behaviors; lower frequencies of these responses were observed in NC900 males and their partners. Facegrooming was less frequent than nosing in $\mathrm{NC100}$ interactions, but $\mathrm{NC100}$ mice still engaged in this response more often than their $\mathrm{C} 3 \mathrm{H}$ partners. Face-grooming was a rare event in NC900 interactions. Sniffing the back and tail were not frequently observed in the NC100 and NC900 social exchanges. SR, composed of boxing, holding, vocalizing, eyeclosing, and kicking behaviors, was not frequently observed in NC100 social interactions (Supplementary Figs. S1G-S1H). By comparison, except for eye-closing, NC900 participated in all other forms of SR more frequently than NC100 mice. Interestingly, C3H partners engaged in more boxing and holding than NC900 males, whereas these NC900 animals vocalized and kicked more often. Examination of the six behaviors comprising TP revealed that these activities occurred almost exclusively in NC900 interactions, with the majority of TP responses appearing as feints by NC900 males (Supplementary Figs. S2AS2B). The frequencies of attack responses and bites were similar in NC900 mice and were observed solely in NC900 interactions (Supplementary Figs. S2D-S2E). Intriguingly, vehicle-treated NC900 targets were more likely to bite their partners than attack. Collectively, these findings suggest that NC900 males were less likely to approach an unfamiliar mouse in a novel territory, and were more likely to initiate kicking and reactive vocalizations towards social investigations by the $\mathrm{C} 3 \mathrm{H}$ partner, than $\mathrm{NC} 100$ mice. The agonistic responses of NC900 males primarily consisted of feints, bites, and attacks, with bites occurring most frequently. Importantly, social responses of the $\mathrm{C} 3 \mathrm{H}$ were shaped by the actions of the NC900 males where their responses reflected the intensity of the social interaction.

DZ treatment produced selective shifts among the individual behaviors that comprised MSI, ISI, SR, TP, and attack (Supplementary Figs. S1A-S1I and S2A-S2F; Supplementary Table S3). DZ increased approach behavior (MSI) and nosing (ISI), while it reduced social reactivity (SR) and shifted agonistic responses from bites and attacks (attack) to feints and 
climb-grooming (TP). Interestingly, behaviors of the $\mathrm{C} 3 \mathrm{H}$ partners were also changed as a function of DZ treatment of NC900 males. Here, NC900 males become more approachable by the $\mathrm{C} 3 \mathrm{H}$ partners and were less reactive; however, attacks and bites were increased in the partners. These changes in behavior occurred, for the most part, in a dose-dependent manner with the individual behaviors in each domain being differentially responsive to DZ treatments.

\section{Discussion}

\subsection{NC900 mice display anxiety-like behaviors that are responsive to DZ}

In the open field, overall locomotor activities were similar between NC100 and NC900 animals. Nonetheless, NC900 mice spent less time in the center zone and engaged in more thigmotaxis than NC100 animals. As reduced time in the center zone or increased locomotion in the perimeter are taken as indices of anxiety in rodents $[63,64]$, these data suggest that NC900 mice may possess an anxiety-like phenotype. Another test of this behavior is the light-dark exploration test where anxious mice avoid brightly lit environments [17]. Since the latencies to enter the lighted chamber and numbers of crosses into this chamber were prolonged while times spent in the lighted side were reduced in NC900 mice, these findings support the idea that NC900 mice present with an anxiety-like phenotype. Finally, animals were tested in the zero maze where reduced time in the open areas is indicative of anxiety [58]. NC900 mice not only spent reduced time in the open areas, but they also took longer to enter the open areas and engaged in fewer transitions than NC100 animals. In a separate investigation using the plus maze, line differences in anxietylike responses were not evident and were attributed to hyperactivity in the maze [32]. This feature is a well-known limitation of the plus maze and does not confound zero maze tests [58]. Collectively, our findings provide high face validity for anxiety-like behaviors and suggest these responses are a stable characteristic of NC900 mice [see 25].

In the present studies, anxiety-like behaviors were pharmacologically validated with DZ in the zero maze. Although NC100 and NC900 mice were both responsive to the anxiolytic effects of DZ, their responses were somewhat different. NC100 mice initially spend more time in the open areas of the maze, but as the dose increases they spend less time in these zones because they are engaging in inactivity. By comparison, open area time is enhanced for NC900 mice as the dose increases. Similarly, the latency to enter the open areas becomes protracted with increasing dose for NC100 mice, whereas it is reduced for NC900 animals. The numbers of transitions decline for $\mathrm{NC100} \mathrm{mice} \mathrm{as} \mathrm{the} \mathrm{dose} \mathrm{is} \mathrm{increased,} \mathrm{while} \mathrm{they} \mathrm{are}$ increased for NC900 males. Parenthetically, these results are all consistent with the fact that DZ has somewhat sedating effects in NC100 mice as is seen in the wire hang experiment. In the zero maze the dose-dependency of the response was shifted to the right for NC900 animals. Interestingly, a similar shift in decreased benzodiazepine sensitivity is seen in some patients diagnosed with anxiety disorder [45,53,54]. Additionally, treatment-resistant anxiety disorder is associated with diminished $\mathrm{GABA}_{\mathrm{A}}$ receptor binding in the frontal cortex $[34,43]$. Hence, the relative decreased response of NC900 mice to the anxiolytic actions of DZ may be due to reduced GABAergic inhibition in brain regions controlling anxiety-like behaviors.

\subsection{NC900 mice show a general reduction in response to DZ}

To determine whether reduced responses to DZ in the zero maze were generalized in NC900 animals, additional behaviors were evaluated. No mouse-line differences were observed under vehicle conditions in the wire-hang, rotorod, or contact righting tests, suggesting that neither line was impaired under basal conditions. Although NC900 mice were significantly less responsive to $\mathrm{DZ}$ in the wire-hang and contact righting tests than $\mathrm{NC100}$ animals, 
rotorod performance was not distinguished by mouse line. These findings are consistent with various studies showing that effects of $\mathrm{DZ}$ are mediated by different $\mathrm{GABA}_{\mathrm{A}}$ receptor mechanisms [see 18,37,55,56]. The receptor regulates anxiolytic effects of DZ in limbic areas, whereas mylorelaxant and sedative effects are controlled by motor neurons and the superficial layer of the dorsal horn $[18,56]$. It should be emphasized that the anxiolytic and myorelaxant effects of DZ seem to be mediated by the $a_{2}$ subunit protein [37], while motor impairing effects are regulated through the $a_{1}[55]$ and, at higher doses, the $a_{3}$ subunit protein [18]. Thus, NC900 debilities in the zero maze, wire hang, and contact righting tests are consistent with a selective diminution of the $a_{2}$ subunit protein within the $\mathrm{GABA}_{\mathrm{A}}$ receptor complex.

\subsection{NC900 mice have reduced DZ binding in brain}

One reason why NC900 mice are less responsive to DZ may be due to differences in DZ metabolism and/or altered expression of these receptors. Normally, DZ is rapidly metabolized to DDP, DDP is converted to TMP and finally to OXP, or directly to OXP [61]. While formation of TMP from DDP occurs to some extent in all species, DDP conversion to OXP is the major pathway in rodents. As HPLC analyses failed to demonstrate line differences in DZ metabolism, the differential behavioral responses are probably not attributed to pharmacodynamic properties of the drug. By comparison, there is some evidence that in vivo Ro15-1788 binding is decreased and that $\mathrm{Cl}^{-}$uptake by cortical synaptoneurosomes is reduced in NC900 mice [65]. Our quantitative autoradiography results with Ro15-4513 reveal marked reductions in DZ binding in NC900 mice in multiple brain regions associated with the regulation of emotional responses. Affective aspects of olfaction are mediated through direct connections between the mitral layer of the olfactory bulb and the medial and posteromedial amygdala [15], which shape the behavioral significance of stimuli. Parenthetically, NC900 mice do not appear to be impaired in olfactory responses (unpublished observations). This olfactory information is relayed from the amygdala to orbitofrontal cortex where conscious perception and identification of odors converge [2]. The lateral and basolateral amygdala represent a central hub where a wide-range of emotionrelated processes are integrated with other brain areas (e.g., hippocampus and frontal cortex) [35] through an extensive network of GABAergic neurons [10]. The basolateral amygdala has extensive connections with the central nucleus [57] which sends projections to lateral hypothalamic and brainstem regions to control the autonomic functions. Projections are sent also to the hypothalamic paraventricular nucleus to control pituitary stress responses and to the periaqueductal gray in brainstem to control defensive behaviors [21]. With the exceptions of the central amygdala and lateral hypothalamus, NC900 mice possess reduced DZ-sensitive binding in all these sites. A loss of $\mathrm{GABA}_{\mathrm{A}}$ receptor-mediated inhibition in circuits controlling emotional responses may enhance excitatory drive in emotion pathways that detect, process, and generate defensive responses to threat. Hence, hyper-excitability of these circuits may render NC900 mice more sensitive to anxiety- and aggression-producing stimuli than NC100 animals.

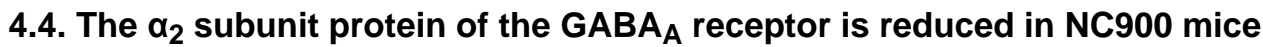

The pharmacological action of $\mathrm{DZ}$ is determined by the subunit composition and expression of the $\mathrm{GABA}_{\mathrm{A}}$ receptor subunits [48]. The benzodiazepine receptor is commonly composed of pentamers of the $a, \beta$, and $\gamma$ subunits [59], where the $a$ and $\gamma$ subunits form the benzodiazepine binding site [8]. Benzodiazepine receptors containing the $a_{1}, a_{2}, a_{3}$, and/or $a_{5}$ subunits and the $\gamma_{2}$ subunit are sensitive to this drug [7,30], and they determine the pharmacologic properties of classical benzodiazepines like DZ. A single histidine residue in the $a_{1}, a_{2}, a_{3}$, and/or $a_{5}$ subunits renders these $G_{A B A}$ receptors responsive to benzodiazepines and replacement of this residue with arginine makes them insensitive to DZ [7,37]. For example, $a_{1}$ H101R knockin mice fail to show sedative and amnesic responses 
to DZ, while anticonvulsant actions of DZ are partially retained [41,55]. Importantly, these mutants retain the anxiolytic-like, motor-impairing, and myorelaxant effects of DZ. By comparison, $a_{2}$ H101R knockin animals are insensitive to DZ anxiolytic actions, whereas $a_{3}$ H101R and $a_{5}$ H101R knockin mice respond to DZ in the light-dark box and elevated plus maze [37,55]. Since DZ does not affect motor or anxiety-like behaviors in $a_{3}$ or $a_{5}$ H101R knockin mice [56], levels of the $a_{1}$ and $a_{2}$ subunit proteins were quantified in amygdala and frontal cortex -- two brain areas well-known to mediate anxiety [20]. The $\gamma_{2}$ subunit was examined also because this subunit is required to form the benzodiazepine binding-pocket and $\gamma_{2}$ heterozygotes display enhanced anxiety that can be reversed with DZ [18]. Although levels of $a_{1}, a_{2}$, or $\gamma_{2}$ mRNAs were similar in the NC lines, some changes in protein concentrations were observed. While levels of $a_{1}$ and $\gamma_{2}$ subunit proteins were indistinguishable by mouse line, concentrations of the $a_{2}$ subunit protein were decreased at least in frontal cortex and amygdala of NC900 mice. These mRNA and protein results indicate that synthesis and/or degradation of the $\alpha_{2}$ subunit protein may be altered in NC900 animals. The selective reduction of the $a_{2}$ subunit protein in NC900 animals and their abnormal responses to DZ in the zero maze and dyadic social tests suggests that heightened anxiety and aggression may be controlled through changes in the levels of this $\mathrm{GABA}_{\mathrm{A}}$ receptor subunit. Additionally, since it has been estimated that up to $15 \%$ of all DZ-sensitive $\mathrm{GABA}_{\mathrm{A}}$ receptors possess the $\mathrm{a}_{2}$ subunit [39] and because this protein is expressed primarily in limbic areas, cerebral cortex, and striatum, our results indicate that anxiety and reactive aggression of NC900 mice may be controlled by these brain regions.

\subsection{DZ reduces reactivity and attack behaviors in NC900 mice}

Compared to NC100 mice, NC900 males demonstrated higher rates of SR and LR along with TP and attack responses. These findings replicate those previously reported in these lines of selectively bred mice $[16,27,28,32,65]$. For the first time, we also report that NC900 males are less likely to engage in more intense forms of social investigation (ISI), whereas the overall durations of milder forms of investigation (MSI) are similar those of NC100 males. Additionally, we show that the social responses of the $\mathrm{C} 3 \mathrm{H}$ partners are dependent upon the social behaviors displayed by the NC900 target mice. Detailed analyses of individual behaviors that comprise the six domains of social behavior by both target and partner mice suggest that NC900 males may be executing defensive rather than offensive agonistic responses. This idea is supported by the observation that NC900 males rarely initiate approaches towards the unfamiliar $\mathrm{C} 3 \mathrm{H}$ partner and show increased instances of defensive boxing, reactive vocalizations, and kicking. Moreover, instead of withdrawing from the novel social stimulus, NC900 males instigate agonistic responses characterized by feints, bites and attacks. The increased incidences of bites relative to attacks and feints indicate that NC900 males engage in agonistic responses that require only brief contact with the $\mathrm{C} 3 \mathrm{H}$ partner, suggestive of responses that reflect the heightened social reactivity and anxiety of the NC900 males in novel contexts. Taken together, the current findings provide strong evidence that $\mathrm{NC} 900$ males view the mild social repertoire of the $\mathrm{C} 3 \mathrm{H}$ partner as threatening and they react to this situation by engaging in defensive agonistic responses.

Since the NC900 males display anxiety-like behaviors and because DZ is known to reduce anxiety-like responses in rodents $[46,58,65]$, effects of this benzodiazepine on social behavior were examined in NC900 mice. It should be emphasized that effects of benzodiazepines on social behavior are controversial, in that they have been reported to exert anti-aggressive effects [49], as well as, disinhibit aggression in humans and animals $[23,42]$. One problem in studies where anti-aggressive influences are found is that the effects may be observed at doses that elicit neuromuscular impairment. In the present studies, we selected doses of DZ that were below the myorelaxant effects on the wire-hang test for NC900 mice. In our hands, DZ clearly reduced behavioral reactivity and attack behaviors in 
NC900 mice while increasing approach behaviors. As the dose of DZ increased, sniffing was replaced by the more intense nosing behavior in NC900 males. Simultaneously, SR was reduced in NC900 animals with decreases in defensive boxing, vocalizations, and kicking behaviors. DZ dose-dependently increased TP by NC900 males, while attack and biting behaviors decreased -- suggesting that DZ shifted NC900 social responses to less intense agonistic behaviors. The reductions in bites, as feints and climb-grooming became more prevalent, suggests that DZ shifted responses of NC900 mice to behaviors that require sustained contact with their partners. These data not only support a previous hypothesis that aggression in the NC900 animals reflects fight-flight responses [51], but they also indicate that the aggression in these males is defensive in nature. This is intriguing since it has been reported that the fight-flight responses generate different defensive behaviors depending upon perceptual inputs and the regulation of anxiety and emotional responses [22]. The DZinduced shift in NC900 social responses is also consistent with Blanchard and colleague's [9] interpretation of benzodiazepine effects on rodent defensive behaviors where they found these drugs produced a shift in defensive responses from higher to lower intensities. Our results provide support for this model and suggest this behavioral effect is likely mediated by the ability of benzodiazepines to reduce excitatory activity in the brain circuitry subserving anxiety and/or emotionality. The ability of DZ to attenuate rapid attack and defensive reactivity-related behaviors in NC900 mice suggests that anxiety promotes the reactivity and rapid attack in these animals. However, because anxiety-like and aggressive behaviors were differentially responsive to the various doses of DZ, these behaviors may rely upon interacting and/or separate mechanisms for their full expression.

\subsection{Co-morbidities of anxiety and aggression in NC900 mice}

The co-appearance of high anxiety and high aggression within the same organism is unusual and may seem paradoxical. Human anxiety disorders are often characterized by avoidance, not aggressive behavior [1]. As a result, many animal models of anxiety use avoidance as a means to identify anxiety-like responses [19]. Nevertheless, anxiety and aggression are coexpressed in mice [24] and they can be co-morbid in humans with borderline personality disorder [36,60] and posttraumatic stress disorder [5,6,40]. Both human conditions are associated with reactive, impulsive aggression, and this behavior is thought to be due to hyperarousal of threat detection systems [44] and may be caused by reductions in benzodiazepine receptors [12]. Since avoidance and aggressive behaviors are defensive responses that involve negative affective, hyper-vigilant, and attentional biases towards sources of threat $[4,21]$, avoidance and aggression may share similar neural substrates when regulation of emotion is impaired.

As high and low aggression are reliably elicited in NC900 and NC100 animals, respectively, these mouse lines are uniquely suited to evaluate the contributions of genetic and environmental factors to the development and expression not only of aggression, but also of anxiety and emotional dysregulation. From our findings it is tempting to speculate that selection for high- and low-aggression in the NC mouse lines also involved concurrent selection for high and low reactivity through changes in DZ-sensitive GABAergic mechanisms in emotion-related brain areas. According to this scheme, selection for high aggression involved concomitant selection for hyper-responsiveness to conspecific social stimuli as mediated by hyperexcitable emotional brain substrates -- mechanisms similar to those thought to underlie human aggression [21]. While NC line differences in DZ-sensitive $\mathrm{GABA}_{\mathrm{A}}$ receptor binding and $\mathrm{a}_{2}$ subunit protein expression may reflect differential regulation of benzodiazepine receptor subunit composition, changes in GABAergic function may also affect responses in other neurotransmitter systems. Within this context, it will be important in the future to evaluate responses in additional transmitter systems to more fully understand relationships between anxiety and aggression. Results from these studies may 
provide new insights into the pathogenesis and treatment of disorders that have components of anxiety and aggression in humans.

\section{Supplementary Material}

Refer to Web version on PubMed Central for supplementary material.

\section{Acknowledgments}

This work was partially supported by a Veterans Administration (Mid-Atlantic Mental Illness Research, Education, and Clinical Center) grant and unrestricted funds (W.C.W.), NIH training grants 2-T32-HD007376 and T32 ES007126 (D.L.N.), and NIH Center For Developmental Science grant 1 P50 MH52429 (J.-L.G., D.L.N.). We wish to thank Drs. Jack Keene and Dhanrajan Tiruchinapalli at the Duke University Medical Center for helping with real-time RT-PCR, Ms. Lindsey E. Phillips for her assistance in the behavioral studies, and The Separations Group, Hisperia, CA for supplying the HPLC column for separation of DZ and its metabolites.

\section{References}

[1]. American Psychiatric Association. Diagnostic and Statistical Manual of Mental Disorders. 4th ed. American Psychiatric Association; Washington, DC: 1994. p. 429-485.

[2]. Anderson AK, Christoff K, Stappen I, Panitz D, Ghahremani DG, Glover G, Gabrieli JD, Sobel N. Dissociated neural representations of intensity and valence in human olfaction. Nat Neurosci. 2003; 6:196-202. [PubMed: 12536208]

[3]. Bakemann, R.; Gottman, JM. Observing Interaction: An Introduction to Sequential Analysis. 2nd ed. Cambridge University Press; Cambridge: 1997. p. 58-80.

[4]. Barlow, DH. Anxiety and its Disorders: The Nature and Treatment of Anxiety and Panic. 2nd ed. Guilford Press; New York: 2002.

[5]. Beckham JC, Feldman ME, Kirby AC, Hertzberg MA, Moore SD. Interpersonal violence and its correlates in Vietnam veterans with chronic posttraumatic stress disorder. J Clin Psychol. 1997; 53:859-869. [PubMed: 9403389]

[6]. Begic D, Jokic-Begic N. Aggressive behavior in combat veterans with post-traumatic stress disorder. Mil Med. 2001; 166:671-676. [PubMed: 11515314]

[7]. Benson JA, Löw K, Keist R, Möhler H, Rudolph U. Pharmacology of recombinant $\gamma$ -

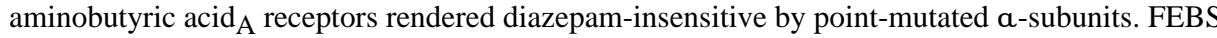
Lett. 1998; 431:400-404. [PubMed: 9714551]

[8]. Berezhnoy D, Nyfeler Y, Gonthier A, Schwob H, Goeldner M, Sigel E. On the benzodiazepine binding pocket in GABA $_{A}$ receptors. J Biol Chem. 2004; 279:3160-3168. [PubMed: 14612433]

[9]. Blanchard DC, Griebel G, Rodgers RJ, Blanchard RJ. Benzodiazepine and serotonergic modulation of antipredator and conspecific defense. Neurosci Biobehav Rev. 1998; 22:597-612. [PubMed: 9662722]

[10]. Bowery N, Hudson A, Price G. GABA $A$ and $\mathrm{GABA}_{B}$ receptor site distribution in the rat central nervous system. Neuroscience. 1987; 20:365-383. [PubMed: 3035421]

[11]. Bradford MM. A rapid and sensitive method for the quantitation of microgram quantities of protein utilizing the principle of protein-dye binding. Anal Biochem. 1976; 72:248-254. [PubMed: 942051]

[12]. Bremner JD, Innis RB, Southwick SM, Staib L, Zoghbi S, Charney DS. Decreased benzodiazepine receptor binding in prefrontal cortex in combat-related posttraumatic stress disorder. Am J Psychiatry. 2000; 157:1120-1126. [PubMed: 10873921]

[13]. Bremner JD, Innis RB, White T, Fujita M, Silbersweig D, Goddard AW, Staib L, Stern E, Cappiello A, Woods S, Baldwin R, Charney DS. SPECT [I-123]iomazenil measurement of the benzodiazepine receptor in panic disorder. Biol Psychiatry. 2000; 47:96-106. [PubMed: 10664825]

[14]. Bućan M, Abel T. The mouse: genetics meets behaviour. Nat Rev Genet. 2002; 3:114-123. [PubMed: 11836505] 
[15]. Buck LB. Information coding in the vertebrate olfactory system. Annu Rev Neurosci. 1996; 19:517-544. [PubMed: 8833453]

[16]. Cairns RB, MacCombie DJ, Hood KE. A developmental-genetic analysis of aggressive behavior in mice: I. Behavioral outcomes. J Comp Psychol. 1983; 97:69-89. [PubMed: 6603330]

[17]. Crawley J, Goodwin FK. Preliminary report of a simple animal behavior model for the anxiolytic effects of benzodiazepines. Pharmacol Biochem Behav. 1980; 13:167-170. [PubMed: 6106204]

[18]. Crestani F, Lorez M, Baer K, Essrich C, Benke D, Laurent JP, Belzung C, Fritschy JM, Luscher $\mathrm{B}$, Möhler H. Decreased $\mathrm{GABA}_{\mathrm{A}}$-receptor clustering results in enhanced anxiety and a bias for threat cues. Nat Neurosci. 1999; 2:833-839. [PubMed: 10461223]

[19]. Cryan JF, Holmes A. Model organisms: The ascent of mouse: advances in modelling human depression and anxiety. Nat Rev Drug Discov. 2005; 4:775-790. [PubMed: 16138108]

[20]. Davidson RJ. Anxiety and affective style: role of prefrontal cortex and amygdala. Biol Psychiatry. 2002; 51:68-80. [PubMed: 11801232]

[21]. Davidson RJ, Putnam KM, Larson CL. Dysfunction in the neural circuitry of emotion regulation -- a possible prelude to violence. Science. 2000; 289:591-594. [PubMed: 10915615]

[22]. Derryberry, D.; Reed, MA. Information processing approaches to individual differences in emotional reactivity. In: Davidson, RJ.; Scherer, KR.; Goldsmith, HH., editors. Handbook of Affective Sciences. Oxford University Press; New York: 1998. p. 681-697.

[23]. DiMascio A. The effects of benzodiazepines on aggression: reduced or increased? Psychopharmacologia. 1973; 30:95-102. [PubMed: 4576033]

[24]. Ferrari PF, Palanza P, Parmigiani S, Rodgers RJ. Interindividual variability in Swiss male mice: relationship between social factors, aggression, and anxiety. Physiol Behav. 1998; 63:821-827. [PubMed: 9618005]

[25]. Fuchs, E.; Flugge, G. Animal models of anxiety disorders. In: Charney, DS.; Nesler, EJ., editors. Neurobiology of Mental Illness. 2nd ed. Oxford University Press; New York: 2004. p. 546-557.

[26]. Fukui M, Rodriguiz RM, Zhou J, Jiang SX, Phillips LE, Caron MG, Wetsel WC. Vmat2 heterozygous mutant mice display a depressive-like phenotype. J Neurosci. 2007; 27:1052010529. [PubMed: 17898223]

[27]. Gariépy JL, Gendreau PL, Cairns RB, Lewis MH. D1 dopamine receptors and the reversal of isolation-induced behaviors in mice. Behav Brain Res. 1998; 95:103-111. [PubMed: 9754882]

[28]. Gariépy JL, Hood KE, Cairns RB. A developmental-genetic analysis of aggressive behavior in mice (Mus musculus): III. Behavioral mediation by heightened reactivity or immobility? J Comp Psychol. 1988; 102:392-399. [PubMed: 3215014]

[29]. Gendreau PL, Gariépy JL, Petitto JM, Lewis MH. D1 dopamine receptor mediation of social and nonsocial emotional reactivity in mice: effects of housing and strain difference in motor activity. Behav Neurosci. 1997; 111:424-434. [PubMed: 9106681]

[30]. Günther U, Benson J, Benke D, Fritschy JM, Reyes G, Knoflach F, Crestani F, Aguzzi A, Arigoni M, Lang Y, Bluethmann H, Möhler H, Lüscher B. Benzodiazepine-insensitive mice generated by targeted disruption of the $\gamma_{2}$ subunit gene of a-aminobutyric acid type A receptors. Proc Natl Acad Sci USA. 1995; 92:7749-7753. [PubMed: 7644489]

[31]. Henn FA, Vollmayr B. Stress models of depression: forming genetically vulnerable strains. Neurosci Biobehav Rev. 2005; 29:799-804. [PubMed: 15925700]

[32]. Hood KE, Quigley KS. Exploratory behavior in mice selectively bred for developmental differences in aggressive behavior. Develop Psychobiol. 2009; 50:32-47.

[33]. Korpi ER, Kleingoor C, Kettenmann H, Seeburg PH. Benzodiazepine-induced motor impairment linked to point mutation in cerebellar $\mathrm{GABA}_{A}$ receptor. Nature. 1993; 361:356-359. [PubMed: 7678923]

[34]. Kosel M, Rudolph U, Wielepp P, Luginbühl M, Schmitt W, Fisch HU, Schlaepfer TE. Diminished $\mathrm{GABA}_{\mathrm{A}}$ receptor-binding capacity and a DNA base substitution in a patient with treatment-resistant depression and anxiety. Neuropsychopharmacology. 2004; 29:347-350. [PubMed: 14628001]

[35]. LeDoux, J. The Emotional Brain. Simon \& Schuster; New York: 1996.

[36]. Lieb K, Zanarini MC, Schmahl C, Linehan MM, Bohus M. Borderline personality disorder. Lancet. 2004; 364:453-461. [PubMed: 15288745] 
[37]. Löw K, Crestani F, Keist R, Benke D, Brünig I, Benson JA, Fritschy JM, Rülicke T, Bluethmann H, Möhler H, Rudolph U. Molecular and neuronal substrate for the selective attenuation of anxiety. Science. 2000; 290:131-134. [PubMed: 11021797]

[38]. Malizia AL, Cunningham VJ, Bell CJ, Liddle PF, Jones T, Nutt DJ. Decreased brain GABA - $^{-}$ benzodiazepine receptor binding in panic disorder: preliminary results from a quantitative PET study. Arch Gen Psychiatry. 1998; 55:715-720. [PubMed: 9707382]

[39]. Marksitzer R, Benke D, Fritschy JM, Trzeciak A, Bannwarth W, Möhler H. GABA A-receptors: drug binding profile and distribution of receptors containing the $\mathrm{a}_{2}$-subunit in situ. J Recept Res. 1993; 13:467-477. [PubMed: 8383760]

[40]. McFall M, Fontana A, Raskind M, Rosenheck R. Analysis of violent behavior in Vietnam combat veteran psychiatric inpatients with posttraumatic stress disorder. J Trauma Stress. 1999; 12:501-517. [PubMed: 10467558]

[41]. McKernan RM, Rosahl TW, Reynolds DS, Sur C, Wafford KA, Atack JR, Farrar S, Myers J, Cook G, Ferris P, Garrett L, Bristow L, Marshall G, Macaulay A, Brown N, Howell O, Moore KW, Carling RW, Street LJ, Castro JL, Ragan CI, Dawson GR, Whiting PJ. Sedative but not anxiolytic properties of benzodiazepines are mediated by the $\mathrm{GABA}_{\mathrm{A}}$ receptor $\mathrm{a}_{1}$ subtype. Nature Neurosci. 2000; 3:587-592. [PubMed: 10816315]

[42]. Miczek KA, Fish EW, De Bold JF, De Almeida RM. Social and neural determinants of aggressive behavior: pharmacotherapeutic targets at serotonin, dopamine and $\gamma$-aminobutyric acid systems. Psychopharmacology (Berl). 2002; 163:434-458. [PubMed: 12373445]

[43]. Nutt DJ, Malizia AL. Structural and functional brain changes in posttraumatic stress disorder. J Clin Psychiatry. 2004; 65(Suppl 1):11-17. [PubMed: 14728092]

[44]. Pavic L, Gregurek R, Petrovic R, Petrovic D, Varda R, Vukusic H, Crnkovic-Markovic S. Alterations in brain activation in posttraumatic stress disorder patients with severe hyperarousal symptoms and impulsive aggressiveness. Eur Arch Psychiatry Clin Neurosci. 2003; 253:80-83. [PubMed: 12799745]

[45]. Paxinos, G.; Franklin, K. The Mouse Brain in Stereotaxic Coordinates. 2nd ed. Academic Press; London: 2001.

[46]. Pogorelov VM, Rodriguiz RM, Insco ML, Caron MG, Wetsel WC. Novelty-seeking and stereotypic activation of behavior in mice with disruption of the Dat1 gene. Neuropsychopharmacology. 2005; 30:1772.

[47]. Potokar J, Coupland N, Wilson S, Rich A, Nutt D. Assessment of GABA A benzodiazepine receptor (GBzR) sensitivity in patients on benzodiazepines. Psychopharmacology (Berl). 1999; 146:180-184. [PubMed: 10525753]

[48]. Pritchett DB, Sontheimer H, Shivers BD, Ymer S, Kettenmann H, Schofield PR, Seeburg PH. Importance of a novel $\mathrm{GABA}_{\mathrm{A}}$ receptor subunit for benzodiazepine pharmacology. Nature. 1989; 338:582-585. [PubMed: 2538761]

[49]. Randall, LO.; Schallek, W. Pharmacological activity of certain benzodiazepines. In: Effron, DH., editor. Psychopharmacology. Public Health Service Publication; 1968. p. 153-184.

[50]. Rodriguiz RM, Chu R, Caron MG, Wetsel WC. Aberrant responses in social interaction of dopamine transporter knockout mice. Behav Brain Res. 2004; 148:185-198. [PubMed: 14684259]

[51]. Rodriguiz, RM.; Jones, BC.; Gariepy, JL. Biobehavioral modes of adaptation in mice selectively bred for aggression: characterization, plasticity, and malleability. In: Hahn, D., editor. Advancing Research on Developmental Plasticity. NIMH; Rockville MD: 1998. p. 271-273.

[52]. Rogers DC, Fisher EM, Brown SD, Peters J, Hunter AJ, Martin JE. Behavioral and functional analysis of mouse phenotype: SHIRPA, a proposed protocol for comprehensive phenotype assessment. Mamm Genome. 1997; 8:711-713. [PubMed: 9321461]

[53]. Roy-Byrne P, Wingerson DK, Radant A, Greenblatt DJ, Cowley DS. Reduced benzodiazepine sensitivity in patients with panic disorder: comparison with patients with obsessive-compulsive disorder and normal subjects. Am J Psychiatry. 1996; 153:1444-1449. [PubMed: 8890678]

[54]. Roy-Byrne PP, Cowley DS, Greenblatt DJ, Shader RI, Hommer D. Reduced benzodiazepine sensitivity in panic disorder. Arch Gen Psychiatry. 1990; 47:534-538. [PubMed: 2161643] 
[55]. Rudolph U, Crestani F, Benke D, Brünig I, Benson JA, Fritschy JM, Martin JR, Bluethmann H,

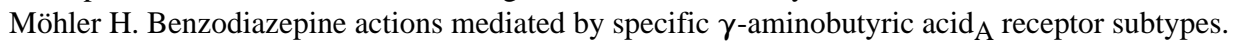
Nature. 1999; 401:796-800. [PubMed: 10548105]

[56]. Rudolph U, Möhler H. Analysis of $\mathrm{GABA}_{\mathrm{A}}$ receptor function and dissection of the pharmacology of benzodiazepines and general anesthetics through mouse genetics. Annu Rev Pharmacol Toxicol. 2004; 44:475-498. [PubMed: 14744255]

[57]. Sah P, Faber ES, Lopez De Armentia M, Power J. The amygdaloid complex: anatomy and physiology. Physiol Rev. 2003; 83:803-834. [PubMed: 12843409]

[58]. Shepherd JK, Grewal SS, Fletcher A, Bill DJ, Dourish CT. Behavioural and pharmacological characterization of the elevated "zero-maze" as an animal model of anxiety. Psychopharmacology (Berl). 1994; 116:56-64. [PubMed: 7862931]

[59]. Sieghart W, Fuchs K, Tretter V, Ebert V, Jechlinger M, Höger H, Adamiker D. Structure and subunit composition of $\mathrm{GABA}_{\mathrm{A}}$ receptors. Neurochem Int. 1999; 34:379-385. [PubMed: 10397365]

[60]. Skodol AE, Gunderson JG, Pfohl B, Widiger TA, Livesley WJ, Siever LJ. The borderline diagnosis I: psychopathology, comorbidity, and personality structure. Biol Psychiatry. 2002; 51:936-950. [PubMed: 12062877]

[61]. St-Pierre MV, Pang KS. Concentration-dependent metabolism of diazepam in mouse liver. J Pharmacokinet Biopharm. 1995; 23:243-266. [PubMed: 8834195]

[62]. Tiihonen J, Kuikka J, Räsänen P, Lepola U, Koponen H, Liuska A, Lehmusvaara A, Vainio P, Könönen M, Bergström K, Yu M, Kinnunen I, Åkerman K, Karhu J. Cerebral benzodiazepine receptor binding and distribution in generalized anxiety disorder: a fractal analysis. Mol Psychiatry. 1997; 2:463-471. [PubMed: 9399689]

[63]. Treit D. Animal models for the study of anti-anxiety agents: a review. Neurosci Biobehav Rev. 1985; 9:203-222. [PubMed: 2861589]

[64]. Treit D, Fundytus M. Thigmotaxis as a test for anxiolytic activity in rats. Pharmacol Biochem Behav. 1988; 31:959-962. [PubMed: 3252289]

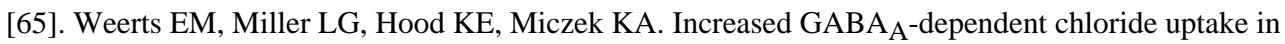
mice selectively bred for low aggressive behavior. Psychopharmacology. 1992; 108:196-204. [PubMed: 1329132] 
(A)

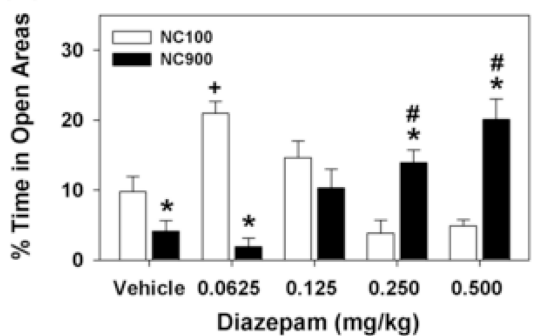

(B)

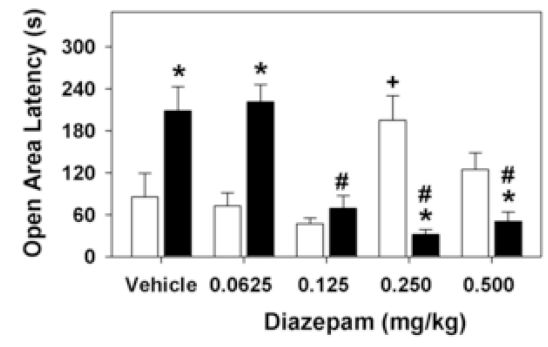

(C)

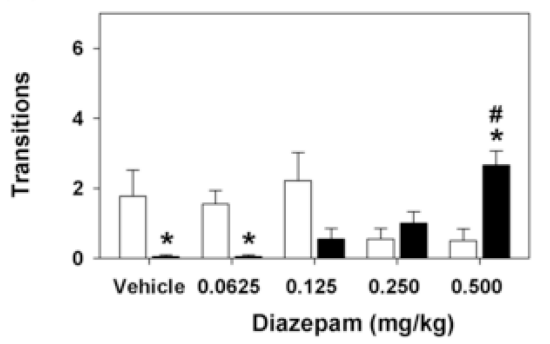

Fig. 1.

Anxiety-like behaviors of NC100 and NC900 mice in the zero maze and response to DZ. Animals were given vehicle or $0.0625,0.125,0.25$, or $0.5 \mathrm{mg} / \mathrm{kg}$ DZ (i.p.) and tested $30 \mathrm{~min}$ later. (A) Percent time in the open areas of the zero maze. (B) Latency to enter the open areas of the maze. (C) Closed to open to closed area transitions. $\mathrm{N}=9$ mice/line/dose. $* p<0.05, \mathrm{NC100}$ versus NC900 animals; $+p<0.05, \mathrm{NC100}$ mice: vehicle versus DZ; $\# p<0.05$, NC900 mice: vehicle versus DZ. 
(A)

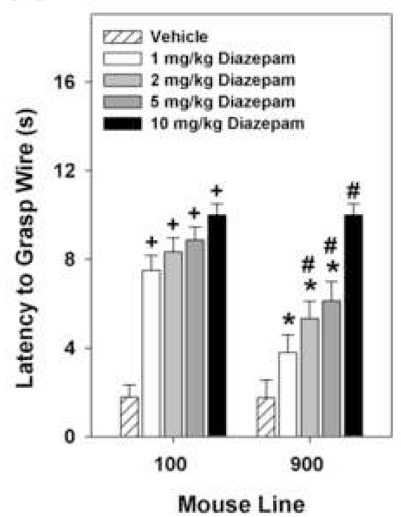

(C)

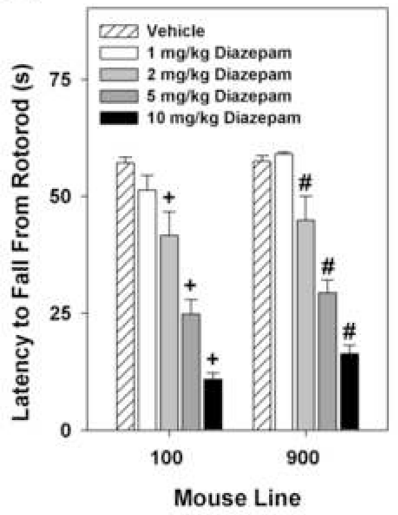

(B)

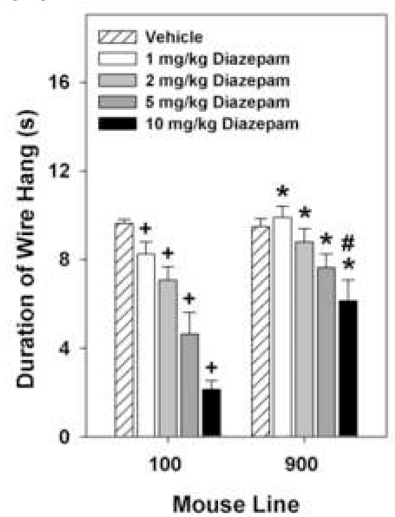

(D)

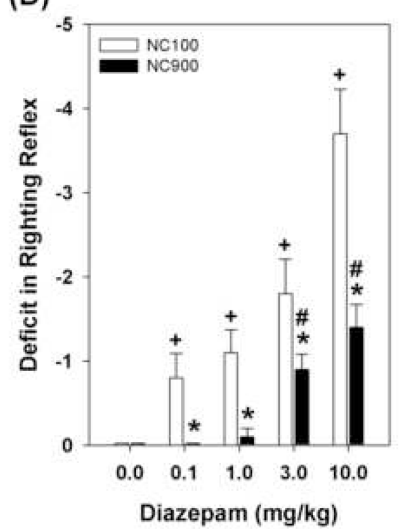

Fig. 2.

Differential myorelaxant and motor-impairing effects of DZ in NC100 and NC900 mice. Animals were pre-trained for 2 days on the rotorod and wire-hang tests, and evaluated with vehicle, $1,2,5$, or $10 \mathrm{mg} / \mathrm{kg}$ DZ (i.p.) $30 \mathrm{~min}$ after injection. (A) Latency to grasp the wire. (B) Duration of wire hang. (C) Latencies to fall from the rotorod. $\mathrm{N}=9-16$ mice/line/dose. (D) Deficits in the contact righting reflex. ${ }^{*} p<0.05$, NC100 versus NC900 animals; $+p<0.05$, NC100 mice: vehicle-controls versus DZ; \# $p<0.05$, NC900 mice: vehicle-controls versus DZ. 


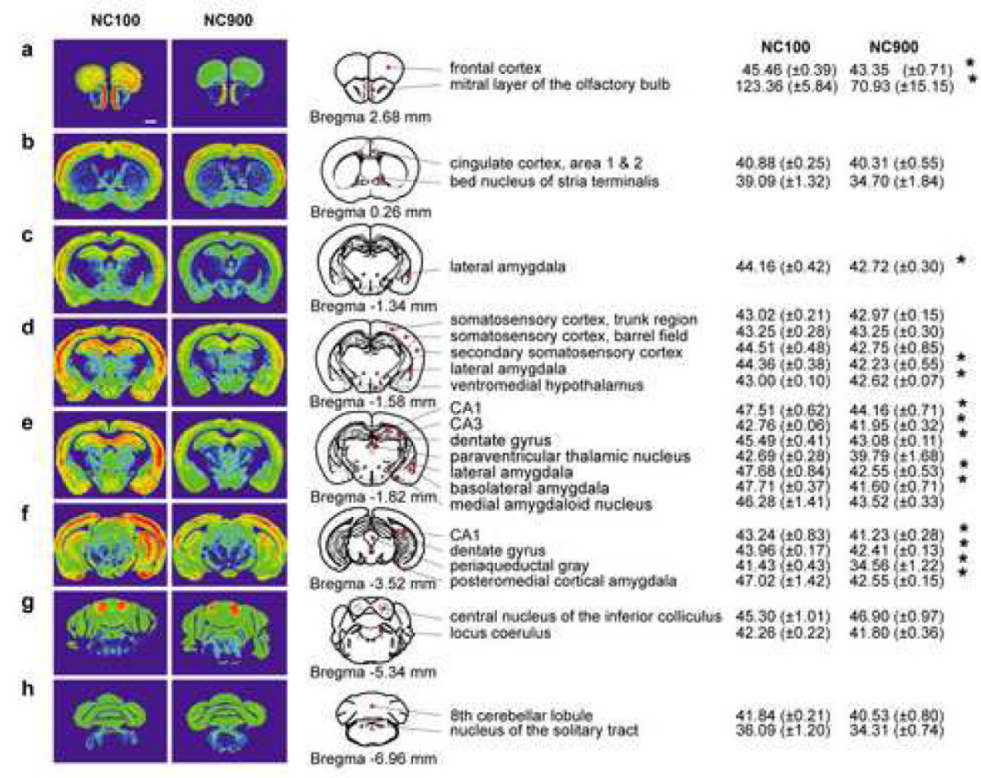

Fig. 3.

Representative autoradiographic distribution of DZ-sensitive binding in coronal sections from NC100 and NC900 brains. (A) Binding in the frontal cortex and mitral layer of the olfactory bulb at $\sim 2.68 \mathrm{~mm}$ bregma [47]. (B) Binding in areas 1-2 of cingulate cortex and bed nucleus of stria terminalis at $\sim 0.26$ bregma. (C) Binding in lateral amygdala at $\sim 1.34$ bregma. (D) Binding in somatosensory cortex, lateral amygdala, and ventromedial hypothalamus at -1.58 bregma. (E) Binding in CA1 and CA3 hippocampus, dentate gyrus, paraventricular thalamus, lateral amygdala, basolateral amygdala, and medial amygdaloid nucleus at $\sim-1.82$ bregma. (F) Binding in CA1 hippocampus, dentate gyrus, periaqueductal gray, and posterior cortical amygdala at $\sim-3.52$ bregma. (G) Binding in the central nucleus of the inferior colliculus and locus coerulus at -5.34 bregma. $(\mathrm{H})$ Binding in the central lobule of the cerebellum and nucleus of the solitary tract at - 6.96 bregma. The values are expressed in $\mu \mathrm{Ci} / \mathrm{g}$ and represent DZ-sensitive binding where $\mathrm{N}=6$ mice/line. Scale bar $=1$ mm. * $p<0.05, \mathrm{NC} 100$ versus NC900 mice. 
(A)

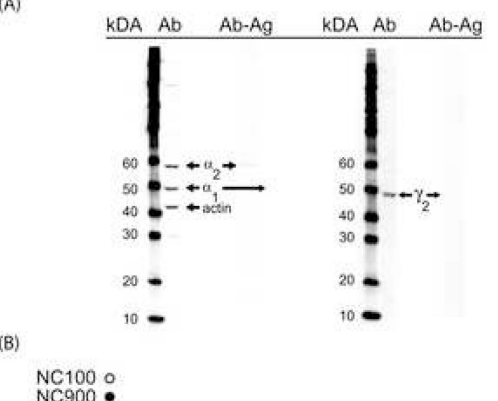

NC100:

Frontal Cortex Amygdala
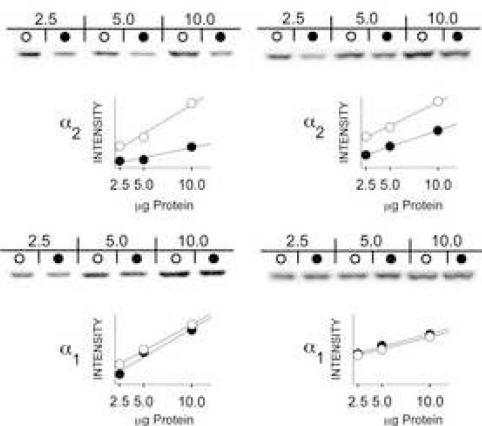

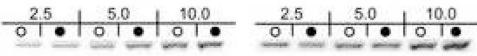
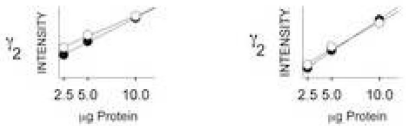

Fig. 4.

Western-blot of $\mathrm{GABA}_{\mathrm{A}}$ receptor $a_{1}, a_{2}$, and $\gamma_{2}$ subunits. (A) Western blot ( $5 \mu \mathrm{g} / \mathrm{lane}$ ) of brain samples with primary $(\mathrm{Ab})$ or pre-absorbed antisera $(\mathrm{Ab}-\mathrm{Ag})$ demonstrating specificity of the $a_{1}, a_{2}, \gamma_{2}$, and $\beta$-actin antisera; immunoreactive bands are shown at approximately 49, 59, 49, and 44 kiloDaltons ( $\mathrm{kDa}$ ), respectively. (B) Representative immunoreactive bands with increasing amounts of total protein $(2.5,5$, and $10 \mu \mathrm{g})$, together with quantification of intensities of $a_{1}, a_{2}$, and $\gamma_{2}$ immunoreactivities in frontal cortex (left) and amygdala (right) from NC100 (open circles) and NC900 mice (filled circles). 

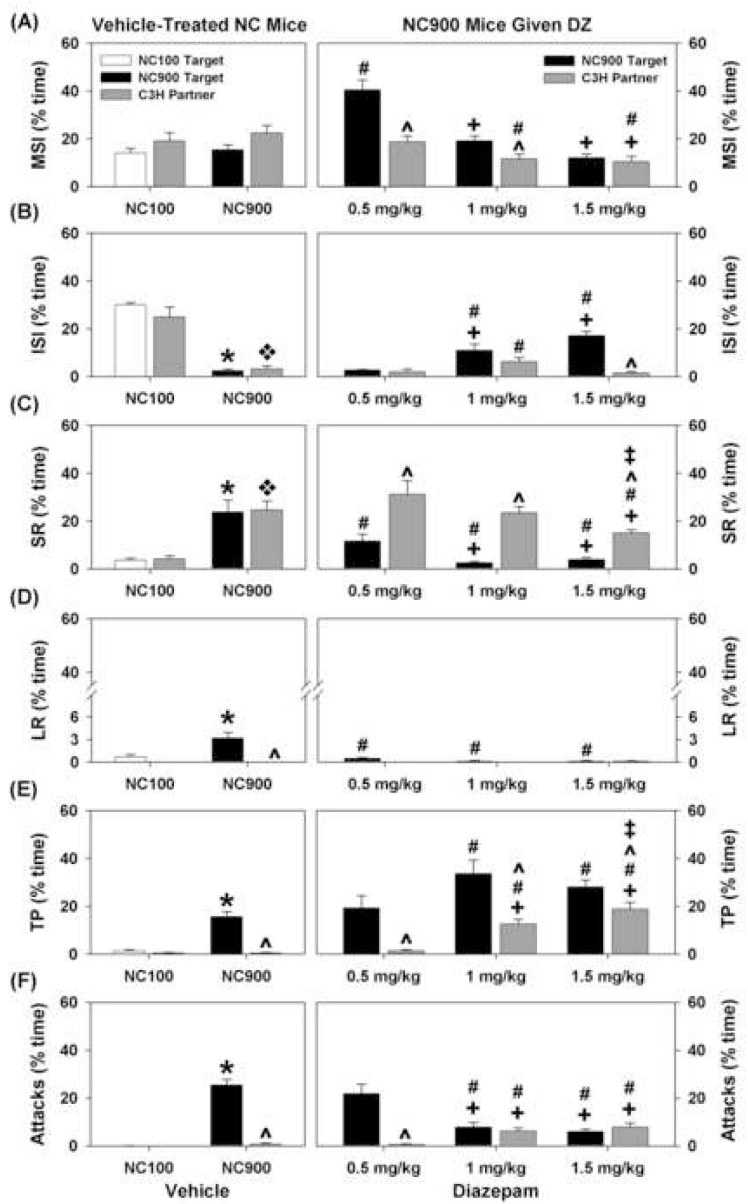

Fig. 5.

Effects of DZ on social behaviors of NC900 males in a dyadic test. $\mathrm{C} 3 \mathrm{H}$ partner males and NC100 animals were untreated. (A) Mild social investigation (MSI). (B) Intensive social investigation (ISI). (C) Stationary reactivity (SR). (D) Locomotor reactivity (LR). (E) Threatening postures (TP). (F) Attacks. N = 9-11 mice/line/dose. ${ }^{*} p<0.05$, NC100 vehiclecontrols versus NC900 vehicle-controls; \#p<0.05, behaviors of NC900 vehicle controls versus $0.5,1$, or $1.5 \mathrm{mg} / \mathrm{kg} \mathrm{DZ}$ or for $\mathrm{C} 3 \mathrm{H}$ partner mice paired to $\mathrm{NC} 900$ vehicle controls versus $\mathrm{C} 3 \mathrm{H}$ partner mice paired to NC900 males treated with $0.5,1$ or $1.5 \mathrm{mg} / \mathrm{kg} \mathrm{DZ}$; $+p<0.05$, NC900 animals treated with $0.5 \mathrm{mg} / \mathrm{kg}$ DZ compared to NC900 males treated with 1 or $1.5 \mathrm{mg} / \mathrm{kg} \mathrm{DZ}$, or C3H partner mice paired to NC900 animals given $0.5 \mathrm{mg} / \mathrm{kg}$ DZ compared to $\mathrm{C} 3 \mathrm{H}$ partner mice paired to $\mathrm{NC} 900$ males given 1 or $1.5 \mathrm{mg} / \mathrm{kg} \mathrm{DZ} ; \ddagger p<0.05$, NC900 mice treated with $1.5 \mathrm{mg} / \mathrm{kg}$ DZ compared to NC900 males treated with $0.5 \mathrm{or} 1 \mathrm{mg}$ / $\mathrm{kg}$ DZ, or C3H partner mice paired to NC900 animals given $1.5 \mathrm{mg} / \mathrm{kg}$ DZ compared to $\mathrm{C} 3 \mathrm{H}$ partner mice paired to $\mathrm{NC} 900$ males given 0.5 or $1 \mathrm{mg} / \mathrm{kg} \mathrm{DZ} ; * p<0.05$, C3H partners paired with $\mathrm{NC} 100$ males versus $\mathrm{C} 3 \mathrm{H}$ partners paired with $\mathrm{NC} 900$ males; ${ }^{\wedge} p<0.05$, NC900 target mice versus its $\mathrm{C} 3 \mathrm{H}$ partners. 
Table 1

Immobility to social contact in NC100 and NC900 animals

\begin{tabular}{llc}
\hline Behavior & Group $^{\boldsymbol{a}}$ & Response \\
\hline Freezing (\% time) & NC100 - Vehicle & $38.6 \pm 1.6$ \\
& NC900 - Vehicle & $0.2 \pm 0.2^{b}$ \\
& NC900 - 0.5 mg/kg DZ & $0.5 \pm 0.3$ \\
& NC900 - $1 \mathrm{mg} / \mathrm{kg} \mathrm{DZ}$ & $1.1 \pm 0.7$ \\
& NC900 - $1.5 \mathrm{mg} / \mathrm{kg} \mathrm{DZ}$ & $1.5 \pm 0.8$ \\
\hline Latency to Freeze (s) & NC100 - Vehicle & $28.6 \pm 3.7$ \\
& NC900 - Vehicle & $204.6 \pm 26.4 c$ \\
& NC900 - 0.5 mg/kg DZ & $190.3 \pm 33.4$ \\
& NC900 - $1 \mathrm{mg} / \mathrm{kg}$ & $\mathrm{DZ} 187.6 \pm 24.8$ \\
& NC900 - $1.5 \mathrm{mg} / \mathrm{kg} \mathrm{DZ}$ & $212.2 \pm 19.5$ \\
\hline
\end{tabular}

${ }^{a} \mathrm{~N}=9-11$ mice/line.

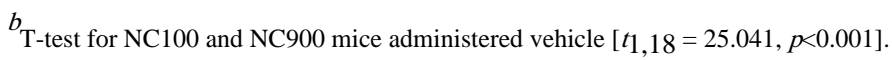

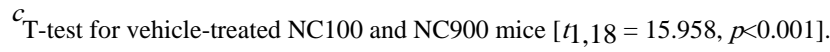


Table 2

Latencies to engage in social behaviors by NC100 and NC900 mice

\begin{tabular}{|c|c|c|}
\hline Domain & Group $^{a}$ & Latency (s) \\
\hline \multirow[t]{5}{*}{ MSI } & NC100 - Vehicle & $6.1 \pm 1.3$ \\
\hline & NC900 - Vehicle & $15.3 \pm 2.3^{b}$ \\
\hline & $\mathrm{NC} 900-0.5 \mathrm{mg} / \mathrm{kg}$ DZ & $4.8 \pm 0.7^{c}$ \\
\hline & NC900 - 1 mg/kg DZ & $3.1 \pm 0.4^{c}$ \\
\hline & NC900 - 1.5 mg/kg DZ & $5.2 \pm 0.9^{c}$ \\
\hline \multirow[t]{5}{*}{ ISI } & NC100 - Vehicle & $21.9 \pm 4.7$ \\
\hline & NC900 - Vehicle & $123.8 \pm 30.4^{d}$ \\
\hline & $\mathrm{NC} 900-0.5 \mathrm{mg} / \mathrm{kg} \mathrm{DZ}$ & $208.1 \pm 24.9^{e}$ \\
\hline & NC900 - 1 mg/kg DZ & $191.4 \pm 14.1^{e}$ \\
\hline & $\mathrm{NC} 900-1.5 \mathrm{mg} / \mathrm{kg} \mathrm{DZ}$ & $238.6 \pm 12.7^{e}$ \\
\hline \multirow[t]{5}{*}{ SR } & NC100 - Vehicle & $136.2 \pm 26.1$ \\
\hline & NC900 - Vehicle & $32.6 \pm 6.8^{f}$ \\
\hline & $\mathrm{NC} 900-0.5 \mathrm{mg} / \mathrm{kg}$ DZ & $40.5 \pm 7.7$ \\
\hline & NC900 - 1 mg/kg DZ & $59.9 \pm 6.9^{g}$ \\
\hline & NC900 - 1.5 mg/kg DZ & $110.6 \pm 9.3 g$ \\
\hline \multirow[t]{5}{*}{ LR } & NC100 - Vehicle & $291.3 \pm 8.7$ \\
\hline & NC900 - Vehicle & $59.4 \pm 7.5^{h}$ \\
\hline & NC900 - 0.5 mg/kg DZ & $131.4 \pm 25.7^{i}$ \\
\hline & NC900 - 1 mg/kg DZ & $246.9 \pm 19.7^{i}$ \\
\hline & NC900 - 1.5 mg/kg DZ & $269.2 \pm 12.4^{i}$ \\
\hline \multirow[t]{5}{*}{$\mathrm{TP}$} & NC100 - Vehicle & $296.7 \pm 3.2$ \\
\hline & NC900 - Vehicle & $38.2 \pm 7.9^{j}$ \\
\hline & NC900 - 0.5 mg/kg DZ & $33.4 \pm 3.8$ \\
\hline & NC900 - 1 mg/kg DZ & $78.3 \pm 10.7^{k}$ \\
\hline & $\mathrm{NC} 900-1.5 \mathrm{mg} / \mathrm{kg} \mathrm{DZ}$ & $173.4 \pm 24.1^{k}$ \\
\hline \multirow[t]{5}{*}{ Attacks } & NC100 - Vehicle & $300.0 \pm 0.0$ \\
\hline & NC900 - Vehicle & $101.5 \pm 11.6^{l}$ \\
\hline & NC900 - 0.5 mg/kg DZ & $97.9 \pm 16.5$ \\
\hline & NC900 - 1 mg/kg DZ & $149.6 \pm 35.2^{m}$ \\
\hline & NC900 - 1.5 mg/kg DZ & $244.9 \pm 17.3^{m}$ \\
\hline
\end{tabular}


${ }^{c}$ ANOVA for NC900 animals given DZ [F3,36 $\left.=15.575, p<0.001\right]$; vehicle versus $0.5 \mathrm{mg} / \mathrm{kg}(p<0.001)$; vehicle versus $1 \mathrm{mg} / \mathrm{kg}(p<0.001)$; vehicle versus $1.5 \mathrm{mg} / \mathrm{kg}(p<0.001)$.

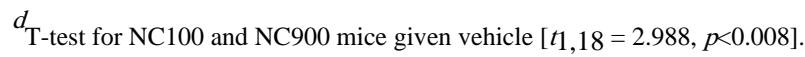

${ }^{e}$ ANOVA for DZ-treated NC900 animals [ $\left.F_{3,36}=8.243, p<0.001\right]$; vehicle versus $0.5 \mathrm{mg} / \mathrm{kg}(p<0.004)$; vehicle versus $1 \mathrm{mg} / \mathrm{kg}(p<0.003)$; vehicle versus $1.5 \mathrm{mg} / \mathrm{kg}(p<0.001)$.

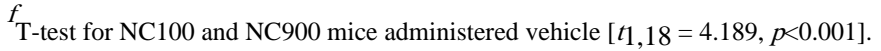

${ }^{g}$ ANOVA for NC900 animals given DZ [F3,36 $\left.=20.471, p<0.001\right]$; vehicle versus $1 \mathrm{mg} / \mathrm{kg}(p<0.006)$; vehicle versus $1.5 \mathrm{mg} / \mathrm{kg}(p<0.001)$.

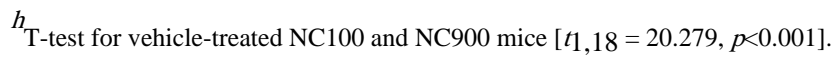

${ }^{i}$ ANOVA for NC900 animals administered DZ [F3,36 = 31.462, $\left.p<0.001\right]$; vehicle versus $0.5 \mathrm{mg} / \mathrm{kg}(p<0.035)$; vehicle versus $1 \mathrm{mg} / \mathrm{kg}(p<0.001)$; vehicle versus $1.5 \mathrm{mg} / \mathrm{kg}(p<0.001)$.

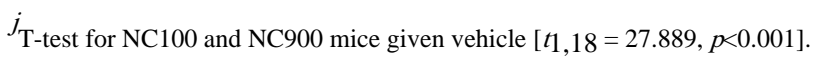

${ }^{k}$ ANOVA for DZ-treated NC900 animals $\left[F_{3}, 36=10.920, p<0.001\right]$; vehicle versus $1 \mathrm{mg} / \mathrm{kg}(p<0.030)$; vehicle versus $1.5 \mathrm{mg} / \mathrm{kg}(p<0.001)$.

${ }^{l}$ T-test for NC100 and NC900 mice administered vehicle $[t 1,18=15.357, p<0.001]$.

${ }^{m}$ ANOVA for NC900 animals given DZ [ $\left.F_{3}, 36=11.931, p<0.001\right]$; vehicle versus $1 \mathrm{mg} / \mathrm{kg}(p<0.033)$; vehicle versus $1.5 \mathrm{mg} / \mathrm{kg}(p<0.001)$. 